\title{
Four-membered rings from isocyanides: Developments since the mid 1980s
}

\author{
Dietrich Moderhack \\ Institute of Medicinal and Pharmaceutical Chemistry, Technical University of Braunschweig \\ D-38106 Braunschweig, Germany, Beethovenstraße 55 \\ E-mail:d.moderhack@tu-bs.de
}

Dedicated to Professor Rosa M. Claramunt on the occasion of her $65^{\text {th }}$ birthday

\begin{abstract}
Reactions of isocyanides with open-chain and cyclic substrates leading to four-membered rings are reviewed. The survey is intended to be illustrative rather than encyclopedic.
\end{abstract}

Keywords: Isocyanides, cyclization, insertion, heterocycles, element-organic rings

\section{Table of Contents}

1. Introduction

2. Reaction of isocyanides with open-chain substrates

2.1. $[1+1+2]$ Cycloaddition of isocyanides to double and triple bond systems

2.2. [1+2] Cycloaddition of isocyanides to double bond systems and subsequent reactions

2.3. [1+3] Cycloaddition of isocyanides to 1,3-dipoles

2.4. Addition of isocyanides to carbenes (including analogs) and subsequent reactions

2.5. Addition of isocyanides to Fischer carbene complexes and subsequent reactions

2.6. Miscellaneous

3. Reaction of isocyanides with cyclic substrates

3.1. Insertion of isocyanides into three-membered rings

3.2. Migratory insertion of isocyanides into metallacycles

3.3. Ring transformation

4. Conclusions

References 


\section{Introduction}

Within the wide area of cyclizations involving the isocyano group the direct formation of fourmembered rings constitutes an especially intriguing process because of elements of serendipity. The first discoveries date back to the 1960s and were summarized at the end of the decade. ${ }^{1}$ The period till 1985, however, proved prolific to such an extent as to warrant a second review. ${ }^{2}$ Since that time again new results have emerged in great number; this may justify the present survey. ${ }^{3}$ Viewing the rich material, two features stand out: (i) The ring-forming principles have almost trebled so as to exclude an introductory graphic of the kind shown in ref. ${ }^{2}$; (ii) regarding the type of products, a plethora of element-organic rings have arisen. ${ }^{4}$

Adhering to style and format of the earlier review, ${ }^{2}$ presentation of all new material will be arranged according to starting compounds rather than to products or actual mechanisms.

\section{Reaction of isocyanides with open-chain substrates}

\section{1. $[1+1+2]$ Cycloaddition of isocyanides to double and triple bond systems}

Alkenes: While a methylenemalononitrile bearing two acceptor groups like the derivative 2a reacts with tert-butyl isocyanide to produce the cyclobutanediimine 1 (Scheme 1), ${ }^{1}$ benzylidene analogs (even though substituted with a nitro or fluoro group at the phenyl ligand) were shown to take up three molecules of the isocyanide to yield the five-membered ring 3 instead. ${ }^{5}$

Though not being an open-chain substrate, the behavior of the benzocyclobutadiene complex $\mathbf{4}$ may be compared to that of 2a. When two equivalents of tert-butyl isocyanide were added to $\mathbf{4}$, the reagent underwent smooth insertion into both $\mathrm{Zr}-\mathrm{C}$ bonds to eventually afford the Dewarnaphthalene 5, the structure of which was established by X-ray diffraction. ${ }^{6}$ Double insertion of tert-butyl isocyanide had been observed before also with the cyclobutene analog of $\mathbf{4}$, but in that case the carbon atoms of the two isocyanides did not couple to give a four-membered ring. ${ }^{7}$

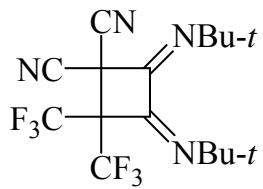

1

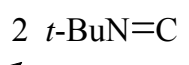

(a)

cf. ref. ${ }^{1}$

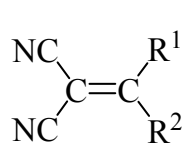

2a: $\mathrm{R}^{1}=\mathrm{R}^{2}=\mathrm{CF}_{3}$

b: $\mathrm{R}^{1}=\mathrm{Ar}, \mathrm{R}^{2}=\mathrm{H}$
$3 \mathrm{RN}=\mathrm{C}$

(b)

i<smiles>[R]NC1=C([Al])C(C#N)(C#N)C(=[R])C1=[W]</smiles>

$3(23-57 \%)$

i: $\mathrm{MeCN}, \Delta \quad \mathrm{Ar}=\mathrm{Ph}, 3 / 4-\mathrm{R}^{\prime} \mathrm{C}_{6} \mathrm{H}_{4} ; \mathrm{R}=t-\mathrm{Bu}, c-\mathrm{C}_{6} \mathrm{H}_{11}$

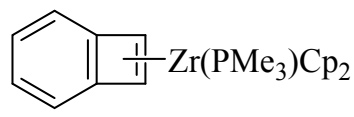

4
$2 t-\mathrm{BuN}=\mathrm{C}$

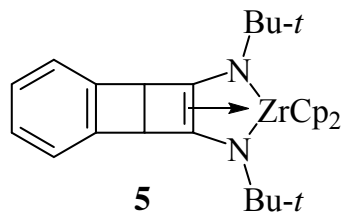

Scheme 1 
Alkynes: Open-chain representatives devoid of an acceptor or donor group are usually inert towards isocyanides. As an exception, a $[1+1+2]$ cycloaddition took place very readily when diphenylethyne was treated with trifluoromethyl isocyanide to afford the cyclobutenediimine 6 (Scheme 2). The structure of this material was determined by an X-ray structure analysis, showing that the imino functions are $E$ and $Z$ configured. Traces of a (mono)ketone arise unless the solvent is rigorously dried. ${ }^{8}$ Similar reactions of this isocyanide were reported - but without experimental details - for but-2-yne and ethoxyethyne, whereas hexafluorobutyne and fluoroalkenes were said to be inert. ${ }^{9}$

However, transition metal-induced [1+1+2] cycloadditions are relatively frequent $\left(c f\right.$. ref. $\left.^{2}\right)$; more recent examples include the following: (i) When oct-4-yne was heated with tert-butyl isocyanide and a catalytic amount of dicarbonylcyclopentadienylcobalt(I), the cyclobutenediimine 7 was obtained. ${ }^{10}$ Yet, on adding - as a fourth component - trimethylsilyl cyanide (which equilibrates with the isocyanide in situ), the pyrrole 8 resulted (or its $N$-unsubstituted congener if tertbutyl isocyanide was replaced with cyclohexyl isocyanide). (ii) When the cationic molybdenum complex 9 was treated with six equivalents of 2,6-dimethylphenyl isocyanide, alkyne-isocyanide coupling gave rise to the four-membered ring 10. ${ }^{11}$ According to the X-ray analysis, the imino groups are configured as observed earlier with the product $6 .{ }^{8}$ - For a further example following the formal $[1+1+2]$ cycloaddition pattern, $c f$. Section 3.2.

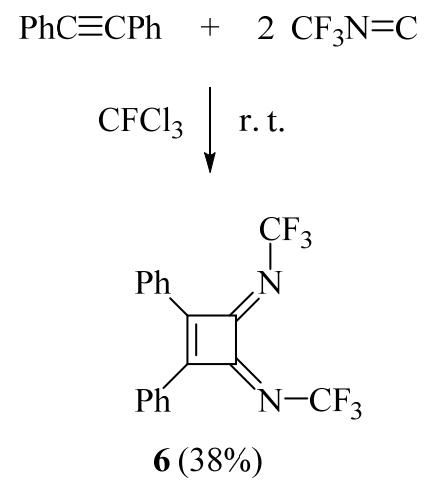

$\left[\begin{array}{c}\mathrm{PhC} \equiv \mathrm{CPh} \\ \mathrm{Cp}{ }_{\mathrm{Mho}(\mathrm{CO})}^{\stackrel{\mathrm{I}}{\equiv} \mathrm{CPh}}\end{array}\right]^{+} \mathrm{BF}_{4}^{-} \underset{\mathrm{THF}, \Delta}{\stackrel{6 \mathrm{ArN}=\mathrm{C}}{\longrightarrow}}$

9
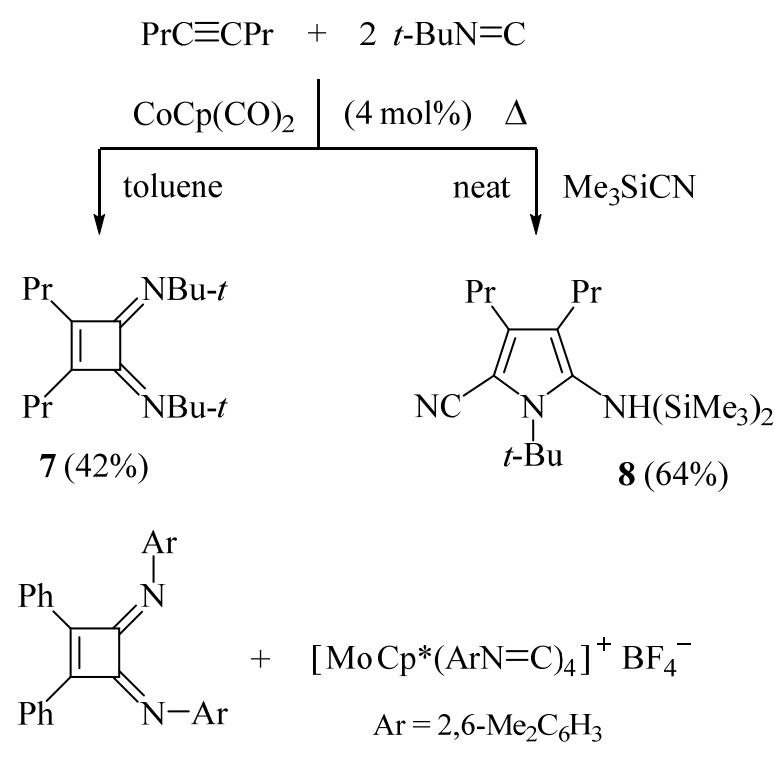

$10(46 \%)$

\section{Scheme 2}

Alkylidene-, imino-, aminoboranes: Compounds of the type $\mathbf{1 1}$ and $\mathbf{1 3}$ were shown to take up two isocyanide molecules very readily (Scheme 3). Treatment of the allene-type system 11 with tertbutyl isocyanide afforded the boretanediimine 12, even when using less than two equivalents of 
the isocyanide. ${ }^{12}$ Accordingly, action of 2,6-dimethylphenyl isocyanide on the iminoborane $\mathbf{1 3}$ led to the 1,2-azaboretidinediimine $14 ;{ }^{13}$ the structure of the product was investigated by X-ray diffraction (a study of $\mathbf{1 2}$ is lacking). Analogous behavior was shown by the aminoborane 15; the product 16, however, was accompanied by compound 17 which resulted from attack of unconsumed 15 on the four-membered ring; its amount increased as the reaction was prolonged. ${ }^{14}$

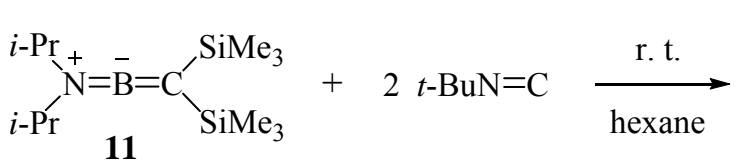

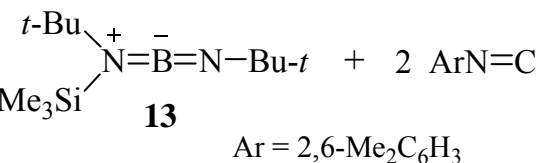
15<smiles>FC(Cl)(Cl)C(Cl)(Cl)Cl</smiles>

$$
\underset{\mathrm{F}_{3} \mathrm{C}^{\prime}}{\mathrm{F}_{3} \mathrm{C}_{-}=\stackrel{+}{\mathrm{N}_{\checkmark}^{\prime}}+2 i-\operatorname{Me}}+\underset{\mathrm{Me}}{\stackrel{\text { r. t. }}{\longrightarrow}}
$$

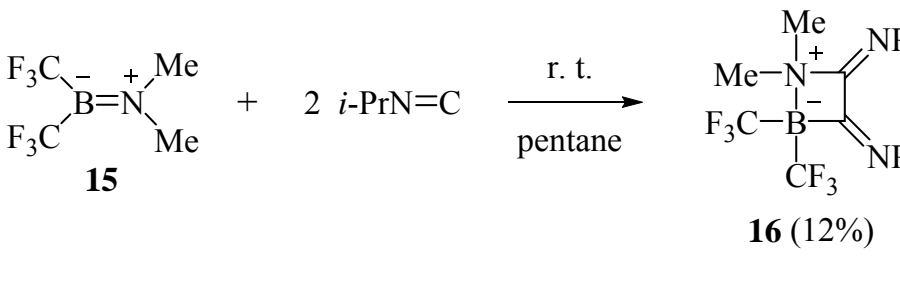

$12(34 \%)$

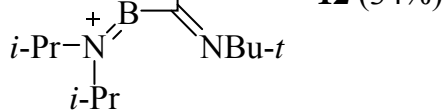

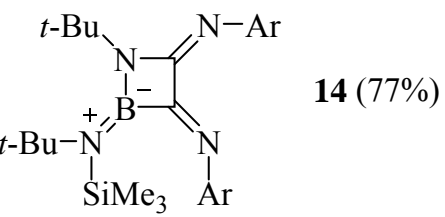

$$
5
$$

\section{Scheme 3}

Imines, thioimidates: A new example for addition of two isocyanide molecules across the $\mathrm{C}=\mathrm{N}$ double bond of an imine is represented by the process $18 \rightarrow \mathbf{1 9}$ (Scheme 4). The experiment has been carried out along with studies on $\alpha, \beta$-unsaturated imines which, however, afforded aminopyrrole derivatives instead of analogs of $19 .{ }^{15}$ The thioimidate unit of the salts 20a,b could be converted into an azetidine using tert-butyl and isopropyl isocyanide ( $\rightarrow$ 21a-c). But a competing reaction gave the 2-aminoimidazoles 22a-e (by involvement of the $\mathrm{HC}^{-}=\mathrm{NR}_{2}$ moiety of 20). ${ }^{16}$

\section{2. [1+2] Cycloaddition of isocyanides to double bond systems and subsequent reactions}

Diphosphenes: Experiments with this class showed that the resultant ring type depends on the substituents (Scheme 5): 23a reacts with methyl or trifluoromethyl isocyanide to give the stable diphosphiranimines 24a,b, whereas bis[2,4,6-tri-(tert-butyl)phenyl]diphosphene combines with the latter isocyanide in a 1:3 ratio to afford a 1,3-azaphospholidine derivative instead. ${ }^{17}$ Threemembered rings like 24c,d were also isolated when the metal-substituted diphosphene $\mathbf{2 3 b}$ was reacted with phenyl or trifluoromethyl isocyanide; the same holds for the reaction of the latter component with the analogous substrate $(\mathbf{2 3 c} \rightarrow \mathbf{2 4 e}) \cdot{ }^{18}$ However, treatment of $23 \mathrm{c}$ with several 
ary $1^{18}$ and alkyl isocyanides ${ }^{19}$ led directly to 1,3-diphosphetanediimines like 25a-f; the transient compounds 24f-k, being prone to P-P fission (cf. Section 3.1), were detected spectroscopically.

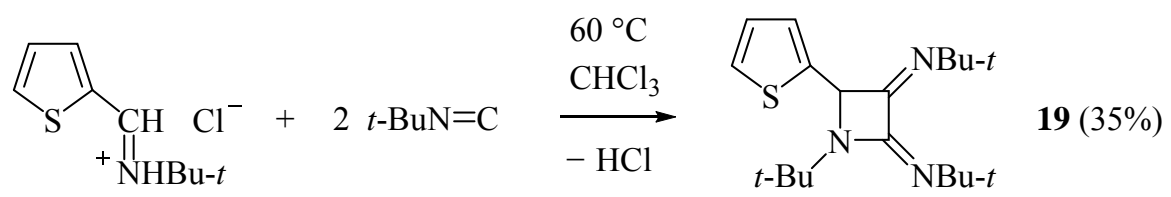

18
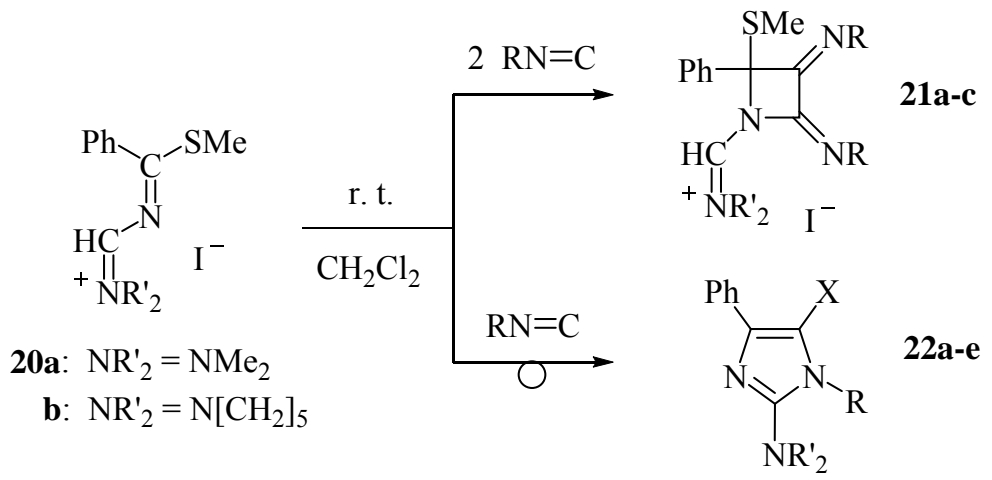

\begin{tabular}{|c|c|c|c|c|c|c|}
\hline 21, 22 & $\mathrm{R}$ & $\mathrm{NR}_{2}$ & $\mathrm{X}$ & $\begin{array}{l}\mathrm{RNC} \\
(\mathrm{mol})\end{array}$ & $\begin{array}{l}\text { Time } \\
\text { (h) }\end{array}$ & Products (yield, \%) / from \\
\hline $\mathbf{a}$ & $t-\mathrm{Bu}$ & $\mathrm{NMe}_{2}$ & $\mathrm{SMe}$ & 2 & 72 & 21a (8), 22a (20), 22d (42) / 20a \\
\hline b & $i-\operatorname{Pr}$ & $\mathrm{NMe}_{2}$ & $\mathrm{SMe}$ & 5 & 18 & 21a (18), 22a (55) / 20a \\
\hline c & $t-\mathrm{Bu}$ & $\mathrm{N}\left[\mathrm{CH}_{2}\right]_{5}$ & $\mathrm{SMe}$ & 5 & 18 & 21b (30), 22b (44) / 20b \\
\hline d & $t-\mathrm{Bu}$ & $\mathrm{NMe}_{2}$ & $\mathrm{H}$ & 2 & 48 & 21c (16), 22c (28), 22e (25) / 20a \\
\hline e & $t-\mathrm{Bu}$ & $\mathrm{N}\left[\mathrm{CH}_{2}\right]_{5}$ & $\mathrm{H}$ & 4 & 10 & 21c (25), 22c (45) / 20b \\
\hline
\end{tabular}

\section{Scheme 4}

Silenes: Photolysis of the acylsilane 26a using 360-nm radiation generated the silene derivative 27a (Scheme 6). In the presence of one equivalent of tert-butyl isocyanide (a) this compound underwent a [1+2] cycloaddition to give the siliranimine 28a which in turn rearranged into the azasiliridine 29a. ${ }^{20,21}$ When a mixture of this material and 2,6-dimethylphenyl isocyanide (b) was photolyzed, the 1,3-azasiletidin-2-imine 30a resulted. ${ }^{22}$ Extending the experiments to the couples 27a $+(\underline{a}), 27 \mathbf{b}+(\underline{a})$, and 27b $+(\underline{b})$, the expected azasiliridines 29b-d were formed, but these compounds, while eluding isolation, reacted with unconsumed isocyanide and produced the azasiletidines 30b-d. However, under nonphotochemical conditions $\left(-70{ }^{\circ} \mathrm{C}\right.$; dark) preformed 27a and 2,6-dimethylphenyl isocyanide ( $\underline{b}$ ) gave rise to a mixture of the compounds $29 \mathbf{b}$ and $\mathbf{3 0 b}$; this contrasts with the behavior of 27a towards alkyl isocyanides ( $c f$. above and ref. ${ }^{20}$ ), which leads exclusively to the type 29. - Detailed NMR spectroscopic investigations of the products 30a-d have shown the occurrence of two stereoisomers each for $\mathbf{a}$ and $\mathbf{b}$, but only one for $\mathbf{c}$ and d. An X-ray diffraction study of the major isomer of $\mathbf{3 0 b}$ has revealed a $Z / E$ symmetry $(\mathrm{C}=\mathrm{N} /$ 
$\mathrm{C}=\mathrm{C}$ group) as depicted; for brevity, this stereo formula was used here for $\mathbf{3 0 a}, \mathbf{c}, \mathbf{d}$ as well. Yields of 30a-d were not disclosed throughout. ${ }^{22}$

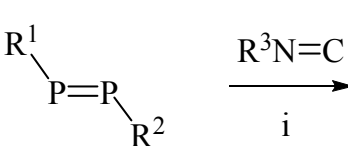

23a-c

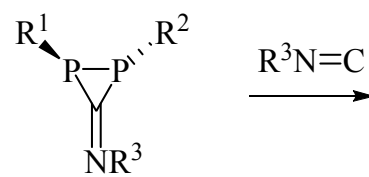

24a-e,[f-k]<smiles>[R4]N=C1P([R])C(=N[R])P1[R]</smiles>

25a-f

i: 0 or $20^{\circ} \mathrm{C} /(n$-)pentane (for 24a-d), 2-methylbutane (24e);

$20{ }^{\circ} \mathrm{C} /$ benzene (for 25a,b), toluene (25d), diethyl ether (25e), neat (25f)

\begin{tabular}{|c|c|c|c|c|c|c|c|}
\hline 23 & 24 & 25 & $\mathrm{R}^{1}$ & $\mathrm{R}^{2}$ & $\mathrm{R}^{3}$ & Yield (\%) ${ }^{c}$ & $E: Z^{\mathrm{d}}$ \\
\hline \multirow[t]{2}{*}{$\mathbf{a}$} & $\mathbf{a}$ & & $\mathrm{C}\left(\mathrm{SiMe}_{3}\right)_{3}$ & $\mathrm{C}\left(\mathrm{SiMe}_{3}\right)_{3}$ & $\mathrm{Me}$ & 61 & \\
\hline & $\mathbf{b}$ & & $\mathrm{C}\left(\mathrm{SiMe}_{3}\right)_{3}$ & $\mathrm{C}\left(\mathrm{SiMe}_{3}\right)_{3}$ & $\mathrm{CF}_{3}$ & 63 & \\
\hline \multirow[t]{2}{*}{ b } & c & & {$[\mathrm{Fe}]^{\mathrm{a}}$} & $\mathrm{C}\left(\mathrm{SiMe}_{3}\right)_{3}$ & $\mathrm{CF}_{3}$ & 31 & \\
\hline & d & & {$[\mathrm{Fe}]$} & $\mathrm{C}\left(\mathrm{SiMe}_{3}\right)_{3}$ & $\mathrm{Ph}$ & 63 & \\
\hline \multirow[t]{7}{*}{ c } & $\mathbf{e}$ & & {$[\mathrm{Fe}]$} & Mes*b & $\mathrm{CF}_{3}$ & 54 & \\
\hline & f & $\mathbf{a}$ & {$[\mathrm{Fe}]$} & Mes* & $\mathrm{Ph}$ & 63 & $2: 1$ \\
\hline & g & $\mathbf{b}$ & {$[\mathrm{Fe}]$} & Mes* & 2- $\mathrm{MeC}_{6} \mathrm{H}_{4}$ & 48 & $2: 1$ \\
\hline & $\mathbf{h}$ & c & {$[\mathrm{Fe}]$} & Mes* & 2,6- $\mathrm{Me}_{2} \mathrm{C}_{6} \mathrm{H}_{3}$ & & \\
\hline & $\mathbf{i}$ & d & {$[\mathrm{Fe}]$} & Mes* & $\mathrm{C}_{6} \mathrm{~F}_{5}$ & 46 & $6: 1$ \\
\hline & $\mathbf{j}$ & e & {$[\mathrm{Fe}]$} & Mes* & $c-\mathrm{C}_{6} \mathrm{H}_{11}$ & 57 & $2: 1$ \\
\hline & $\mathbf{k}$ & f & {$[\mathrm{Fe}]$} & Mes* & $\mathrm{CH}_{2} \mathrm{Ph}$ & 79 & $2: 1$ \\
\hline
\end{tabular}

${ }^{\mathrm{a}}[\mathrm{Fe}]=\mathrm{FeCp} *(\mathrm{CO})_{2} \cdot{ }^{\mathrm{b}}$ Mes $*=2,4,6-(t-\mathrm{Bu})_{3} \mathrm{C}_{6} \mathrm{H}_{2} \cdot{ }^{\mathrm{c}}$ Products 24a-e and 25a-f, respectively (no yield for $25 \mathrm{c}$ ). ${ }^{\mathrm{d}}$ Two $Z$ isomers observed.

\section{Scheme 5}

A later example of this kind of conversion constitutes the reaction of the neopentyl-substituted silene 27c. This substrate - prepared from (dimesitylfluorosilyl)ethene and tert-butyllithium gave the silazetidine $30 \mathbf{e}$ on treatment with two equivalents of tert-butyl isocyanide. ${ }^{23}$

It might be added that azasiliridines related to $\mathbf{2 9}$ were obtained very recently from isocyanides and a disilene like $\mathrm{R}_{2} \mathrm{Si}=\mathrm{SiRPh}\left[\mathrm{R}=2,4,6-(i-\mathrm{Pr})_{3} \mathrm{C}_{6} \mathrm{H}_{2}\right]$, but, remarkably, these products (which have a semicyclic $\mathrm{C}=\mathrm{Si}$ bond instead of a $\mathrm{C}=\mathrm{C}$ bond) did not undergo isocyanide insertion to give four-membered rings, i.e. silylidene analogs of $30^{24}$

Phospa-, arsasilenes: Unique derivatives of the type 30, i.e. compounds like 32a-c, arose quantitatively on exposure of the 'heterosilenes' $\mathbf{3 1} \mathbf{a}^{25}$ and $\mathbf{3 1} \mathbf{b}^{26}$ to mesityl and cyclohexyl isocyanide (Scheme 7). The reaction was assumed to follow the pattern of the preceding paragraph. Treatment of the products 32b,c with hydrogen chloride (or fluoride), however, met with surprise in that arsasilete derivatives 33a,b were isolated; X-ray crystallography served to establish the 
structures of both 32c and 33b. ${ }^{26}$ Extending their ring forming experiments to 1,6-diisocyanohexane, the authors succeeded in converting 31a,b into the corresponding macroheterocycles; of these new products, the arsa representative has also been studied by X-ray diffraction. ${ }^{27}$
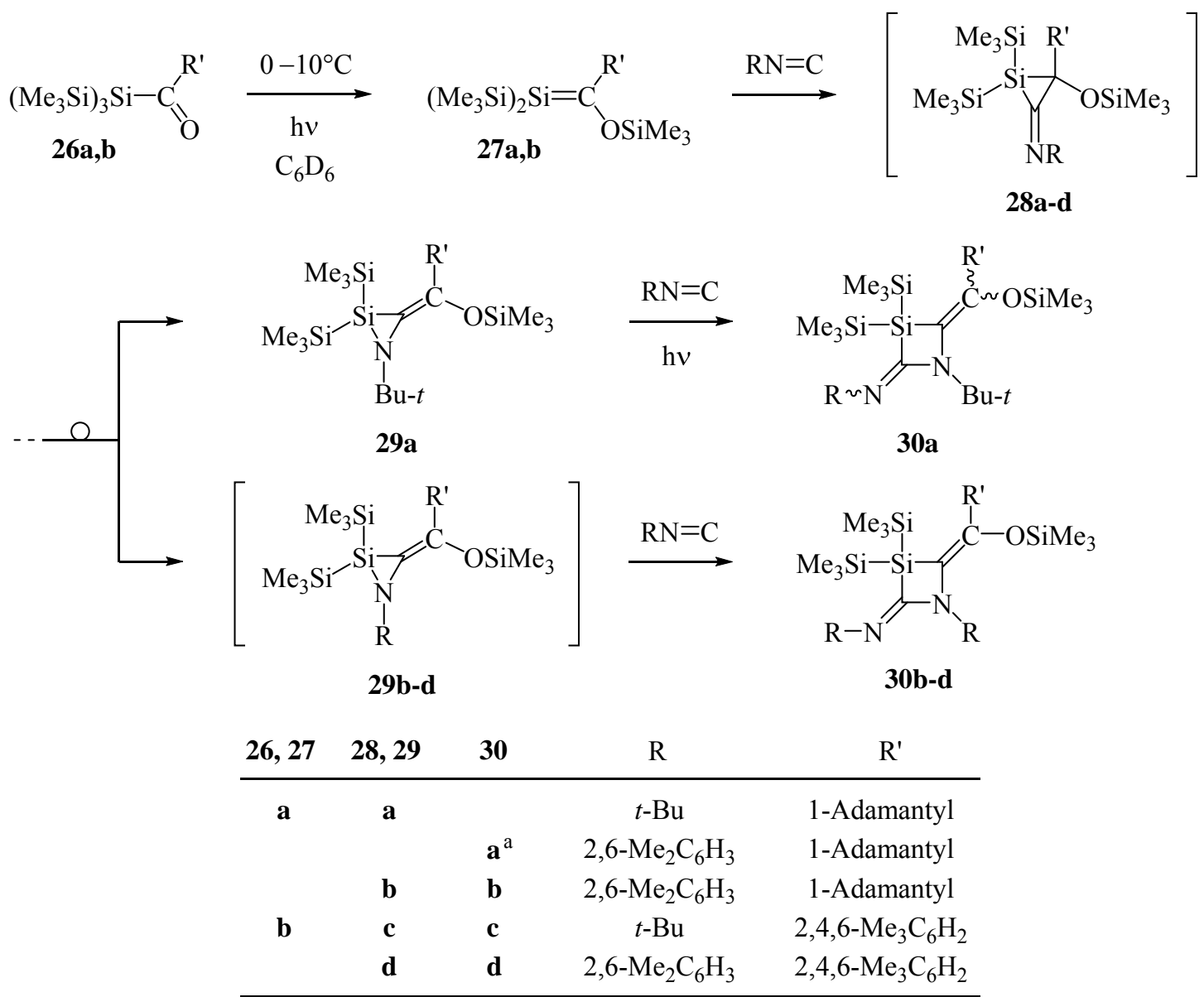

${ }^{\text {a }}$ Compound 30a isolated as mixed species of two geometric isomers in about 3:2 proportions.

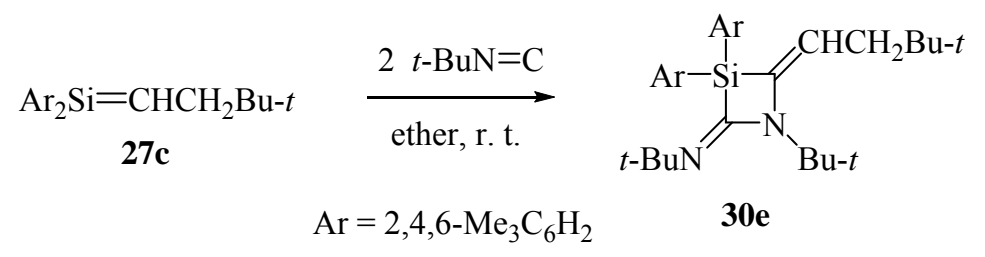

\section{Scheme 6}




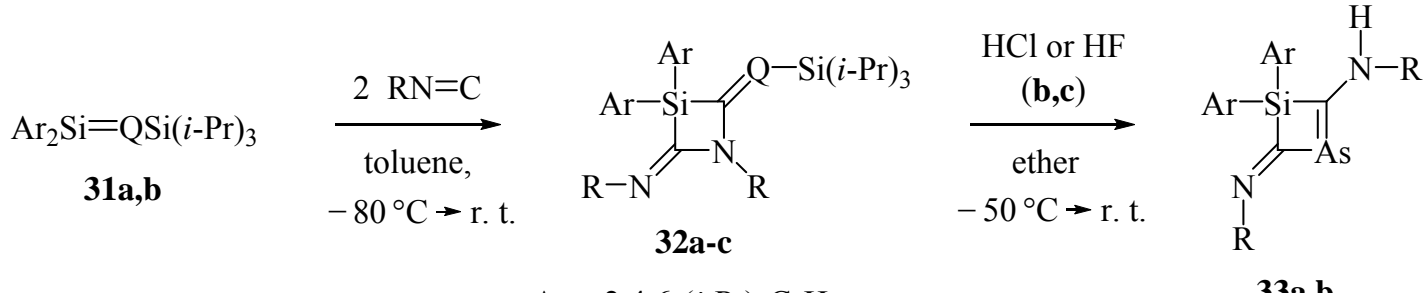

$$
\begin{aligned}
& \mathrm{Ar}=2,4,6-(i-\mathrm{Pr})_{3} \mathrm{C}_{6} \mathrm{H}_{2}
\end{aligned}
$$

\begin{tabular}{ccccc} 
31 & 32 & 33 & $\mathrm{Q}$ & $\mathrm{R}$ \\
\hline $\mathbf{a}$ & $\mathbf{a}$ & & $\mathrm{P}$ & $2,4,6-\mathrm{Me}_{3} \mathrm{C}_{6} \mathrm{H}_{2}$ \\
$\mathbf{b}$ & $\mathbf{b}$ & a & $\mathrm{As}$ & $2,4,6-\mathrm{Me}_{3} \mathrm{C}_{6} \mathrm{H}_{2}$ \\
& c & b & As & $c-\mathrm{C}_{6} \mathrm{H}_{11}$
\end{tabular}

\section{Scheme 7}

\section{3. [1+3] Cycloaddition of isocyanides to 1,3-dipoles}

Nitrile imines: Detailed studies on the behavior of $N$-aryl nitrile imines towards isocyanides ${ }^{28-32}$ have shown that the title reaction occurred under certain conditions. ${ }^{29,31,32}$ Best suited are nitrile imines bearing a donor-substituted phenyl group at the terminal nitrogen like 34, they gave cycloadducts 36 with a wide variety of isocyanides (Scheme 8). ${ }^{31,32}$ These four-membered rings, however, eluded isolation, but their formation could be inferred from products formed by [2+2] cycloreversion into benzonitrile and a carbodiimide (37), by ring expansion to a quinoxaline (38), and finally by [2+2] cycloreversion of the secondary adduct 39 into 37 and a 1,2,4-triazole (40). Besides these compounds products such as 41-45 were found; formally, they derive from the linear adduct 35 which in the case $\mathrm{R}=t$-Bu could be detected spectroscopically. ${ }^{33}$

Compared to 34, the proclivity of its $N$-phenyl analog to undergo a [1+3] cycloaddition is low, ${ }^{29}$ and with $\mathrm{Ar}=4-\mathrm{NO}_{2} \mathrm{C}_{6} \mathrm{H}_{4}$ there were no indications at all. ${ }^{32}$ This failure applies also to nitrile imines having an acceptor group at the $C$-terminus like an $\operatorname{acyl}^{31}$ or a 4-nitrophenyl substituent. $^{32}$ 


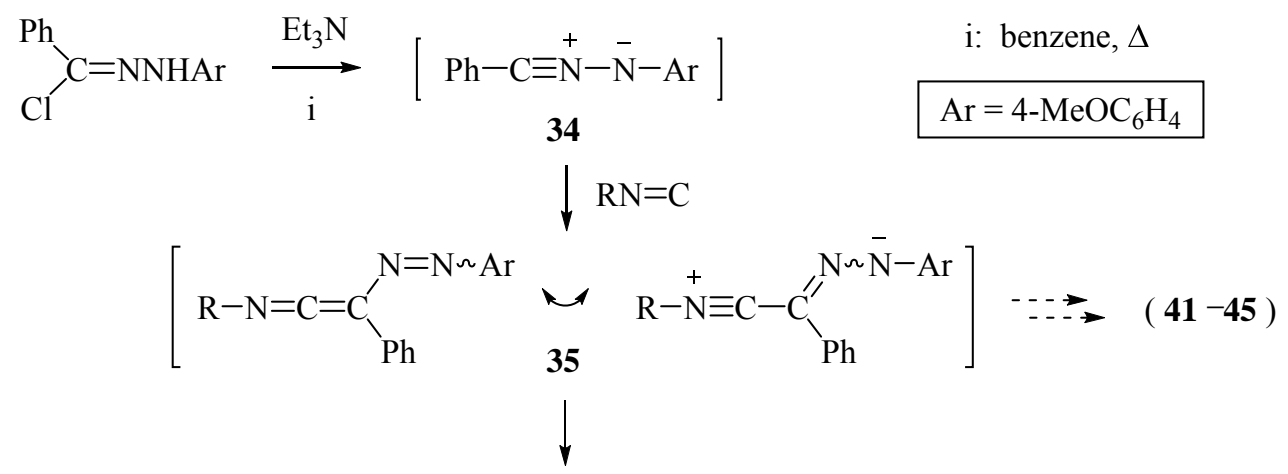

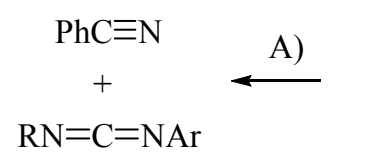

37a-f

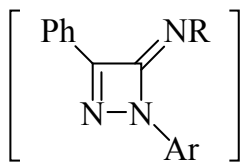

36<smiles>[R]Nc1nc2ccc(OC)cc2nc1-c1ccccc1</smiles>

38a-f

B) $\downarrow 34$
A) = major
B) $=$ minor<smiles>[Y17]N1C(=N)C2(c3ccccc3)[Al]N1N=C2C</smiles>

39

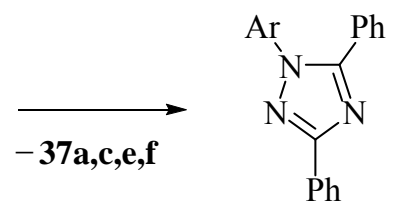

40<smiles>C/C(=N\N(N)[Al])c1ccccc1</smiles>

41<smiles>[R][n+]1c(-c2ccccc2)nn([Al])c1C(=[N+])c1ccccc1</smiles>

42a: $\mathrm{R}=i-\mathrm{Pr}$

b: $\mathrm{R}=c-\mathrm{C}_{6} \mathrm{H}_{11}$<smiles>[Al]N1N=C(c2ccccc2)N(c2c(-c3ccccc3)nn([Al])c2N[AlH2])[Al]1c1ccccc1</smiles><smiles>CCOC(=O)C1N([Al])N=C(c2ccccc2)C2N([Al])N=C(c3ccccc3)N12</smiles>

44<smiles>CCNN=C(c1ccccc1)c1ncc(OCC)o1</smiles>

45

\begin{tabular}{lccccc}
$\mathbf{3 7}$ & Yield (\%) $^{\mathrm{a}}$ & $\mathrm{R}$ & $\mathbf{3 8}$ & Yield $(\%)$ & Other / Yield (\%) \\
\hline $\mathbf{a}$ & 49 & $i-\mathrm{Pr}$ & $\mathbf{a}$ & 15 & $\mathbf{4 0} / 2, \mathbf{4 2 a} / 8$ \\
$\mathbf{b}$ & 19 & $t-\mathrm{Bu}$ & $\mathbf{b}$ & 3 & $\mathbf{4 1}$ b $/ 27$ \\
$\mathbf{c}$ & 43 & $c-\mathrm{C}_{6} \mathrm{H}_{11}$ & $\mathbf{c}$ & 25 & $\mathbf{4 0} / 2, \mathbf{4 2 b} / 10, \mathbf{4 3} / 6$ \\
$\mathbf{d}^{\mathrm{c}}$ & & $\mathrm{CH}_{2} \mathrm{CO}_{2} \mathrm{Et}$ & $\mathbf{d}$ & 18 & $\mathbf{4 4} / 31, \mathbf{4 5} / 7$ \\
$\mathbf{e}$ & 37 & $4-\mathrm{MeOC}_{6} \mathrm{H}_{4}$ & $\mathbf{e}$ & 21 & $\mathbf{4 0} / 6$ \\
$\mathbf{f}$ & 62 & $2,6-\mathrm{Me}_{2} \mathrm{C}_{6} \mathrm{H}_{3}$ & $\mathbf{f}$ & 17 & $\mathbf{4 0} / 5$ \\
\hline
\end{tabular}

${ }^{a}$ Yield based on the respective urea. ${ }^{\mathrm{b}}$ By elimination of isobutene from transient 1-tert-butyl-2-(4-methoxyphenyl)-5-phenyl-2H-1,2,3-triazolium. ${ }^{\mathrm{c}}$ Carbodiimide 37d apparently unstable.

\section{Scheme 8}


Azomethine imines: In contrast to the aryl functionalized CNN moiety in 46a which, using tertbutyl isocyanide, was earlier cyclized to a 1,2-diazetidine ring (47), ${ }^{2}$ the acyl group in the congener 46b, as shown recently, confers upon the molecule a 1,5-dipolar character which led to the formation of a 1,3,4-oxadiazine cycle (48) (Scheme 9). ${ }^{34}$
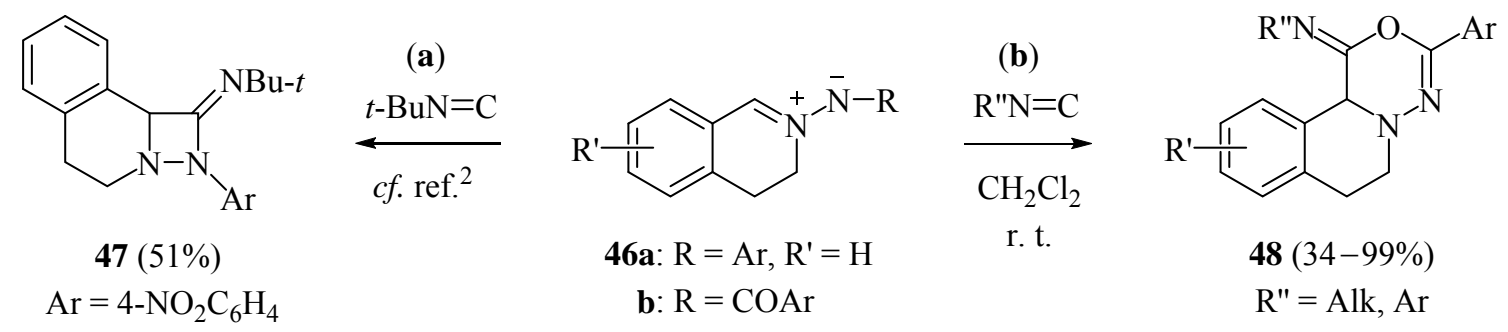

\section{Scheme 9}

Nitrones: The known cyclization ${ }^{2}$ of the nitrone 49 with cyclohexyl isocyanide to give the 1,2oxazetidin-4-imine 50 has recently been duplicated for mechanistic purposes (Scheme 10). ${ }^{35}$ To rationalize their synthesis of $\alpha$-oxoamides from $N$-alkylhydroxylamines and aliphatic aldehydes under the conditions of the Ugi reaction, the authors thought of $\mathbf{5 0}$ as one possible intermediate and submitted this model to their procedure. But, being aware of an old observation, ${ }^{36}$ they confirmed that $\mathrm{N}-\mathrm{O}$ cleavage in $\mathbf{5 0}$ occurred with deprotonation of the $\mathrm{N}$-methyl group $(\rightarrow \mathbf{5 1})$, not at $\mathrm{C}(3)$ which would be necessary for the production of an $\alpha$-oxoamide.

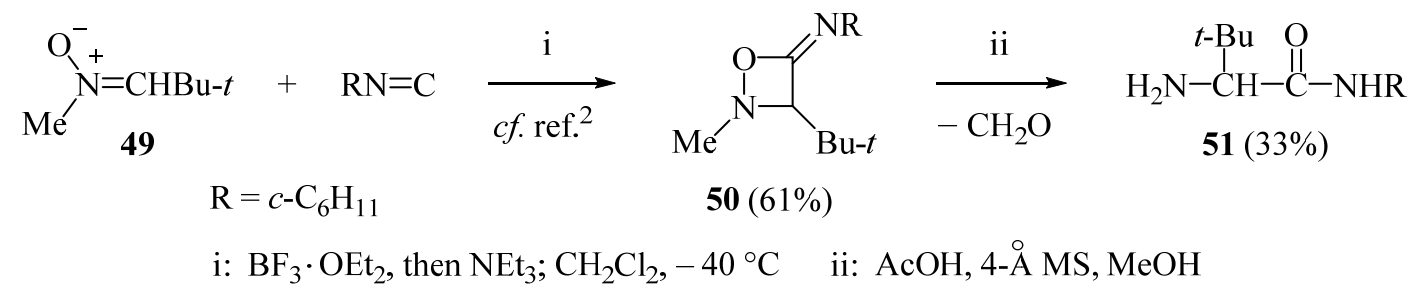

\section{Scheme 10}

Diphosphinoketenimines: Although representing no classical 1,3-dipoles, the title substrates 52 were shown to behave as such (Scheme 11). In the presence of water they reacted with isocyanides to give compounds of the type $\mathbf{5 4}$ that were proposed to arise via four-membered rings like 53/53'. Labeling experiments demonstrated that the oxygen and ring-attached hydrogen of 54 originate from the external water; in a rigorously dried medium no reaction occurred. ${ }^{37}$ 


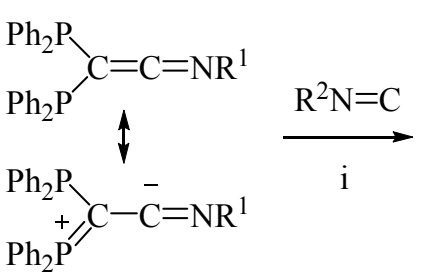

52

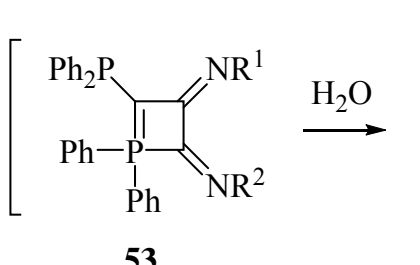

53

i: $\mathrm{THF} / \mathrm{H}_{2} \mathrm{O}$, r. t.

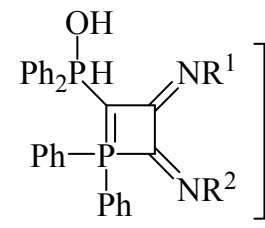

53

$\mathrm{R}^{1}=\mathrm{Ar} \quad \mathrm{R}^{2}=\mathrm{Alk}, \mathrm{Ar}$

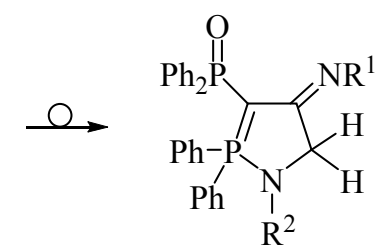

54

\section{Scheme 11}

(For 1,3-dipolar behavior of metal-coordinated ketenimines, see Section 2.5.)

\subsection{Addition of isocyanides to carbenes (including analogs) and subsequent reactions}

Carbenes: The phosphino(silyl)carbene 55a, generated from the corresponding diazo precursor, reacted with pentafluorophenyl isocyanide to give the dihydro-1,2-azaphosphete 57a, which was established by an X-ray analysis (Scheme 12). The process was explained to involve a transient ketenimine (56a) that undergoes a $\mathrm{P} / \rightarrow \mathrm{C} /$ migration of one $\mathrm{NR}_{2}$ group, followed by electrocyclization of the resultant 1-aza-4-phosphabutadiene. ${ }^{38,39}$ When reacting the arylsubstituted carbene 55b with tert-butyl isocyanide, the respective ketenimine $\mathbf{5 6 b}$ could be characterized spectroscopically, but at room temperature it rearranged slowly into the analogous ring system $\mathbf{5 7 b} .^{40}$

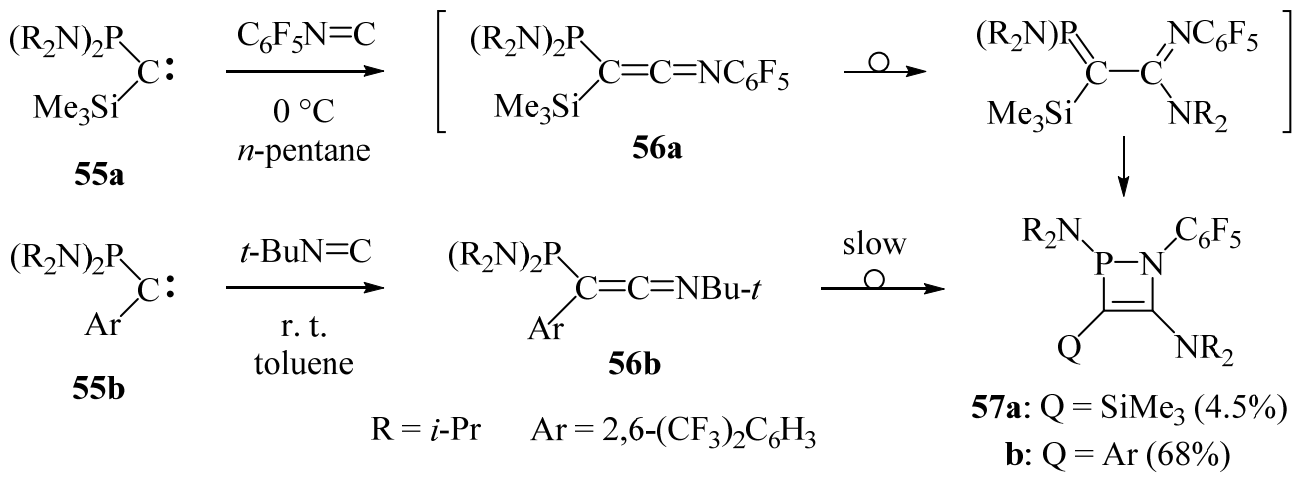

\section{Scheme 12}

Silylenes: Photolysis of the trisilirane 58 in the presence of isocyanides has been shown to afford disiletanediimines of the type $\mathbf{6 1}$ and $\mathbf{6 2}$ (Scheme 13). These compounds arose by coupling of the silylene 59 with the isocyanide to give the silaketenimine $\mathbf{6 0}$ which in turn cyclodimerized. The reaction was performed with phenyl ${ }^{41}$ and sterically crowded aryl isocyanides, ${ }^{42}$ but also with isocyanides bearing electron-withdrawing groups. ${ }^{43}$ As expected, head-to-tail cyclodimerization prevails; only when using 2,6-diisopropylphenyl isocyanide the head-to-head mode occurred too, 
giving minor amounts of the derivative 62c. ${ }^{42}$ While no yield figure was disclosed in that work, it was later detailed that the derivatives 61c and 62c were isolated in a ratio of ca. 10:1 (regardless of the reaction conditions) and that they were not interconverted photochemically. ${ }^{44}$ The molecular geometry of 61a,c,d and 62c has been determined by X-ray crystallography. ${ }^{41-43}$

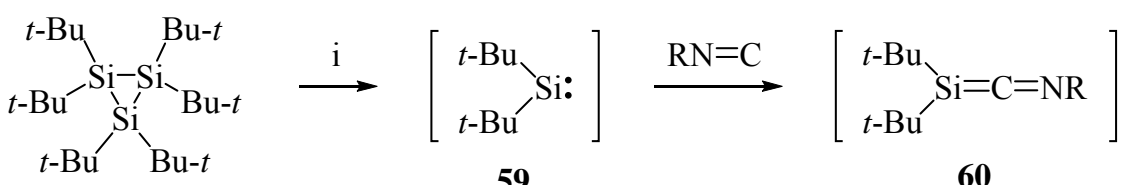

58

59<smiles>[R]N=C1C(=N[R])[Si](Br)(Br)[Si]1(Br)Br</smiles>

i: hv, r. t.; light petroleum, $n$-pentane or $n$-hexane

62c

\begin{tabular}{cccccc} 
61 / 62 & $\mathrm{R}$ & Yield (\%) & $\mathbf{6 1}$ & $\mathrm{R}$ & Yield (\%) \\
\hline $\mathbf{a}$ & $\mathrm{Ph}$ & 65 & $\mathbf{d}$ & $\mathrm{CF}_{3}$ & 72 \\
b & $2,4,6-\mathrm{Me}_{3} \mathrm{C}_{6} \mathrm{H}_{2}$ & 45 & e & $\mathrm{C}_{6} \mathrm{~F}_{5}$ & 50 \\
c & $2,6-(i-\mathrm{Pr})_{2} \mathrm{C}_{6} \mathrm{H}_{3}$ & $76 /$ minor & f & $3,5-\left(\mathrm{CF}_{3}\right)_{2} \mathrm{C}_{6} \mathrm{H}_{3}$ & 59
\end{tabular}

\section{Scheme 13}

Surprising behavior was encountered with the (stable) silylene 63. On treatment with cyclohexyl isocyanide two competing reactions occurred (Scheme 14): (i) $\alpha$-addition of the CN and $c-\mathrm{C}_{6} \mathrm{H}_{11}$ moieties of the fragmented reagent furnished the carbonitrile 64; (ii) linear coupling of intact isocyanide led to the silaketenimine 65; this intermediate, in contrast to species 60 (cf. Scheme 13), took up another isocyanide to generate a four-membered ring $(\rightarrow \mathbf{6 6})$; stabilization of its carbene function by uptake of a third isocyanide, followed by hydrogen migration from the cyclohexylimino group, gave the product $\mathbf{6 7}$, the structure of which was established by the X-ray method. ${ }^{45}$

Borylenes: An interesting borylene-to-isocyanide transfer resulting in the final formation of the four-membered rings 70a,b happened when the chromium complex 68 was treated with certain aryl isocyanides (Scheme 15). The reaction assumedly involved a [1+2] cycloadduct (69) that was susceptive to isocyanide insertion. The molecular structure of 70a was elucidated by X-ray diffraction. ${ }^{46}$ 


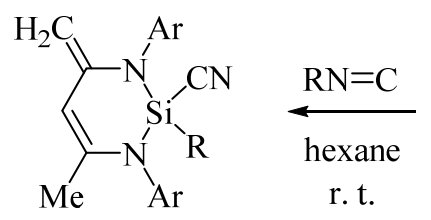
$64(32 \%)$<smiles>C=C1C=C(C)N([Al])[Si]N1[Al]</smiles>

63

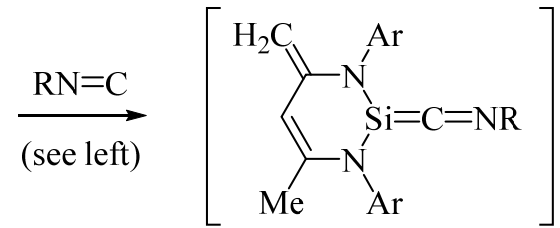

65

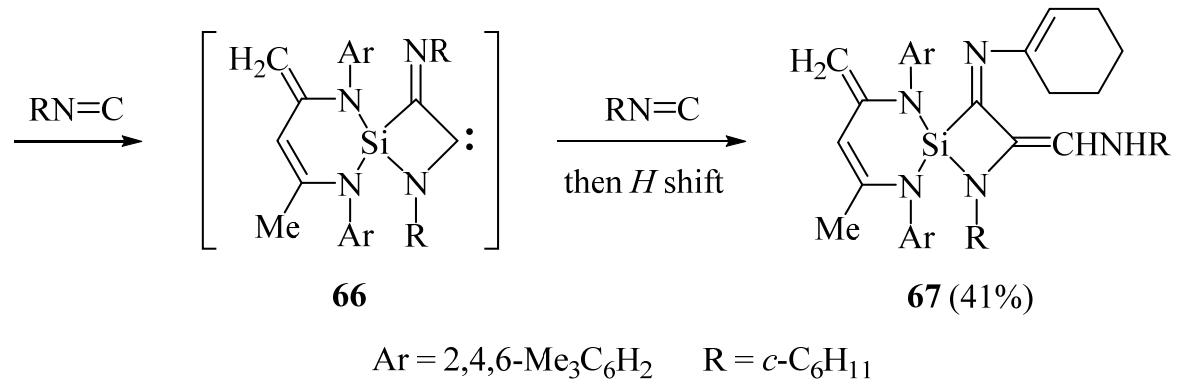

\section{Scheme 14}

$$
\begin{aligned}
& \left(\mathrm{Me}_{3} \mathrm{Si}\right)_{2} \mathrm{~N}=\mathrm{B}=\mathrm{ML}_{\mathrm{n}} \underset{\mathbf{6 8}}{\stackrel{\mathrm{RN}=\mathrm{C}}{\longrightarrow}}\left[\begin{array}{c}
\left(\mathrm{Me}_{6} \mathrm{Si}\right)_{2} \mathrm{~N} \\
\text { r. t. }
\end{array}\right] \stackrel{\mathrm{RN}}{\longrightarrow} \\
& \mathrm{ML}_{\mathrm{n}}=\mathrm{Cr}(\mathrm{CO})_{5} \\
& \mathrm{Ar}^{1}=2,4,6-\mathrm{Me}_{3} \mathrm{C}_{6} \mathrm{H}_{2} \\
& \mathrm{Ar}^{2}=2,6-(i-\mathrm{Pr})_{2} \mathrm{C}_{6} \mathrm{H}_{3}
\end{aligned}
$$

\section{Scheme 15}

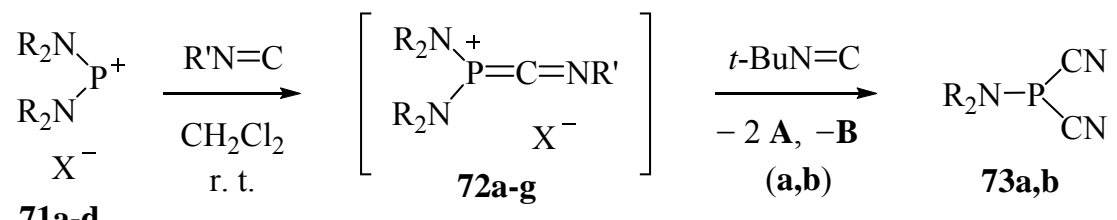

$$
\begin{aligned}
& \text { (b-g) } \downarrow \mathrm{R}^{\prime} \mathrm{N}=\mathrm{C} \\
& \mathbf{A}=\mathrm{H}_{2} \mathrm{C}=\mathrm{CMe}_{2} \quad\left[\begin{array}{c}
\mathrm{R}_{2} \mathrm{~N} \\
\mathrm{R}_{2} \mathrm{~N}-\stackrel{1}{\mathrm{P}}=\mathrm{C}=\mathrm{NR}_{2} \mathrm{NH}_{2}^{+} \mathrm{X}^{-} \\
{ }_{\mathrm{C}}^{\mathrm{C}}=\mathrm{N}_{1} \mathrm{R}^{\prime} \\
\mathrm{X}^{-} \mathrm{R}^{\prime}
\end{array}\right] \longrightarrow
\end{aligned}
$$

\begin{tabular}{cccccccccc} 
71-74 & $\mathrm{R}$ & $\mathrm{R}$ & $\mathrm{X}$ & $\mathrm{Yield}(\%)$ & $\mathbf{7 1 - 7 4}$ & $\mathrm{R}$ & $\mathrm{R}^{\prime}$ & $\mathrm{X}$ & Yield (\%) \\
\hline a & $i-\mathrm{Pr}$ & $t-\mathrm{Bu}$ & $\mathrm{CF}_{3} \mathrm{SO}_{3}$ & & e & $\mathrm{Me}$ & $c-\mathrm{C}_{6} \mathrm{H}_{11}$ & $\mathrm{CF}_{3} \mathrm{SO}_{3}$ & 90 \\
b & $\mathrm{Et}$ & $t-\mathrm{Bu}$ & $\mathrm{CF}_{3} \mathrm{SO}_{3}$ & 50 & $\mathbf{f}$ & $\mathrm{Et}$ & $c-\mathrm{C}_{6} \mathrm{H}_{11}$ & $\mathrm{CF}_{3} \mathrm{SO}_{3}$ & 80 \\
c & $\mathrm{Me}$ & $t-\mathrm{Bu}$ & $\mathrm{CF}_{3} \mathrm{SO}_{3}$ & 92 & $\mathbf{g}$ & $i-\mathrm{Pr}$ & $c-\mathrm{C}_{6} \mathrm{H}_{11}$ & $\mathrm{CF}_{3} \mathrm{SO}_{3}$ & 90 \\
d & $\mathrm{Me}$ & $t-\mathrm{Bu}$ & $\mathrm{AlCl}_{4}$ & 89 & & & & &
\end{tabular}

\section{Scheme 16}


Phospheniums (Addendum): Carbenoid properties are also exhibited by phosphenium salts like 71a-d (Scheme 16). These substrates couple with alkyl isocyanides to give transient phosphaketenimines (72a-g) which, depending on the substituents, react with a second molecule of isocyanide to afford either dicyanophosphine derivatives (73a,b) or imino-substituted dihydro-1,3-azaphosphetium salts (74b-g). When the intermediate $\mathbf{7 2 b}$ took up tert-butyl isocyanide, both routes were followed so as to reduce the yield of the product $\mathbf{7 4 \mathbf { b }} .^{47,48}$

\subsection{Addition of isocyanides to Fischer carbene complexes and subsequent reactions}

Isocyanides combine with Fischer-type carbenes to generate ketenimine complexes of the type A (Scheme 17). The mechanism of the process has recently been studied, showing that $\mathbf{A}$ is formed via a metallacyclopropanimine followed by isomerization and 1,2-metallotropic rearrangement. ${ }^{49}$ Preparatively, these species have turned out to be valuable building blocks for a variety of four-, five-, and six-membered rings (for reviews, see refs. ${ }^{50,51}$ ). Concentrating on the first mentioned class, this section will describe applications of the synthetic principles outlined below. Beyond that, mention will be made of the ring contraction of a single [2+3] cycloadduct obtained from $\mathbf{A}$.

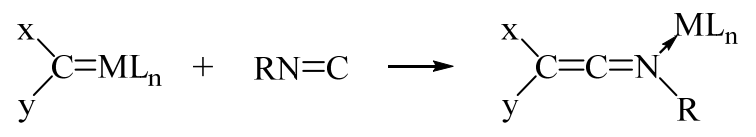

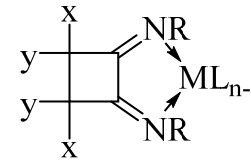

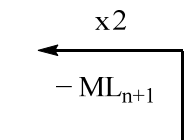<smiles>CC12NC(=NN)C1(C)NO2</smiles><smiles>[R]n1c(=[18O])c(=[18O])c1=[18O]</smiles>

$$
\stackrel{3 \mathrm{RN}=\mathrm{C}}{-\mathrm{RN}=\mathrm{C}=\mathrm{ML}_{\mathrm{n}}}
$$
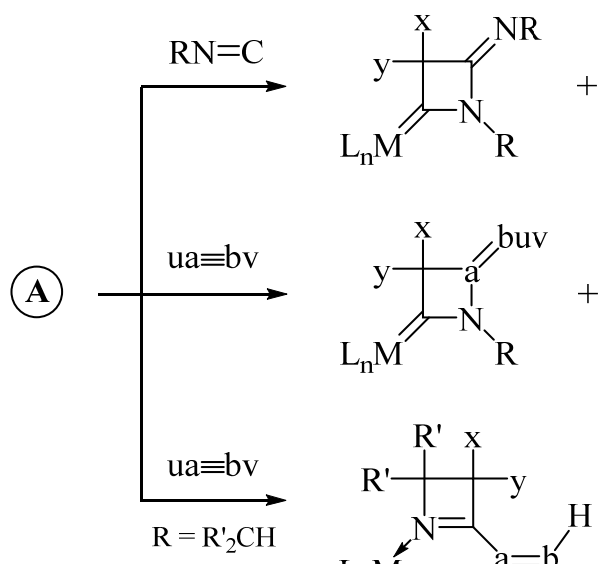<smiles>[Y]C1C(=[W])N([R])C1(C)C</smiles>

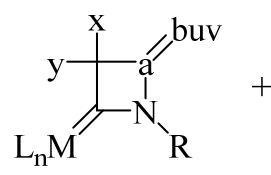<smiles>[R]N1C(=[W])N(I)S1(=O)=O</smiles>

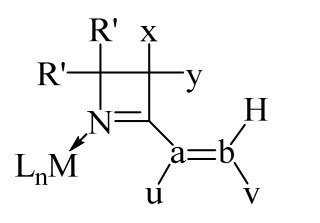

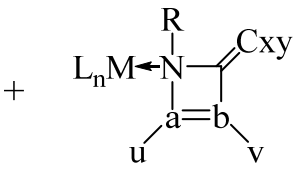

\section{Scheme 17}

Dimerization: Carbene complexes such as $\mathbf{7 5}$ react with alkyl isocyanides to give the corresponding ketenimine complexes 76 (Scheme 18). On being heated in an inert solvent, these coupling products slowly dimerize to afford the metal-coordinated cyclobutanediimines $78^{52-54}$ The symmetrical [2+2] cycloaddition which is unusual for free ketenimines is template-induced and thought to proceed through an intermediate like 77. Part of this remarkable reaction has been reviewed earlier. ${ }^{2}$ 
Intramolecular cycloaddition: Ketenimine complexes bearing an alk-3-enyl moiety at the carbon atom like the derivatives 80a-c undergo, once generated from the precursor 79, an intramolecular $\left[2_{\mathrm{s}}+2_{\mathrm{a}}\right]$ cycloaddition (Scheme 18). Owing to the involvement of the cycloheptatrienyl ligand, the cyclobutanimine unit becomes part of a tricyclic system, as illustrated by the products 81a-c. Of these materials, two stereoisomers were found; the structure of anti-81c has been determined by X-ray crystallography. Attempts to demetalate this derivative with pyridine caused fragmentation of the four-membered ring. ${ }^{55}$
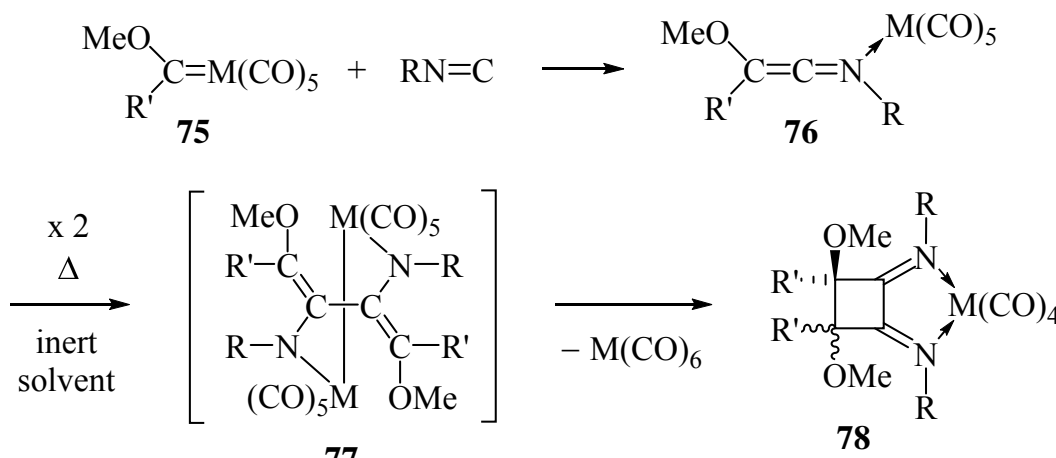

77

$\mathrm{R}^{\prime}=\mathrm{Me}, \mathrm{Ph}, 2$-thienyl, naphthyl (unspecified); $\mathrm{M}=\mathrm{Cr}, \mathrm{Mo}, \mathrm{W} ; \mathrm{R}=\mathrm{Me}, t-\mathrm{Bu}, c-\mathrm{C}_{6} \mathrm{H}_{11}$<smiles></smiles>

79: $\mathrm{M}=\mathrm{Cr}, \mathrm{W}$

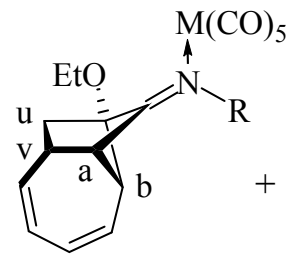

syn-81a-c

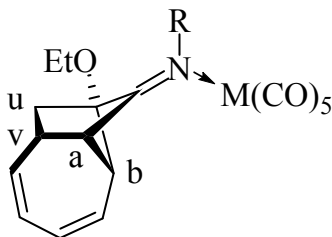

anti-81a-c

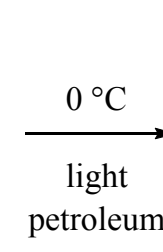

etroleum

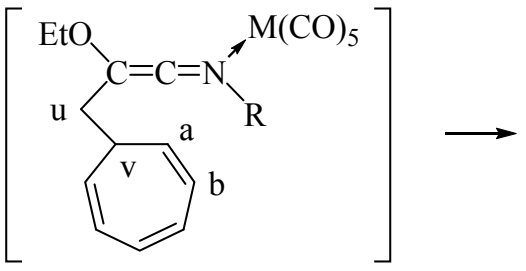

80a-c

\section{Scheme 18}

Addition of isocyanides: Ketenimine complexes exhibit 1,3-dipolaroid properties. Using isocyanides as dipolarophiles, 4-iminoazetidin-2-ylidene complexes can arise (Scheme 19). Success and extent of this reaction depend primarily on the metal. Thus, starting from the iron carbene complex 82a, the desired products, e.g. 84a-d, were obtained in high yield regardless of the nature of the isocyanide; the intermediary ketenimine complexes 83a-d were not observed. ${ }^{56,57}$ Yet, in the 
case of the tungsten complex $\mathbf{8 2} \mathbf{b}$, the $[1+3]$ cycloaddition became a side reaction: Employing benzyl isocyanide, 84e was accompanied by the indanediimine $\mathbf{8 6 a}$ and the complex $\mathbf{8 7 a},{ }^{57}$ and using alkenyl isocyanides, relatively high quantities of the $2 \mathrm{H}$-pyrroles 88a,b were isolated besides the azetidinylidene complexes $\mathbf{8 4 f}, \mathbf{g} .{ }^{58}$ As the compounds 84 readily undergo oxidative demetalation, they are useful precursors to functionalized $\beta$-lactams $(\rightarrow \mathbf{8 5 a}$-c,f $\mathbf{f}){ }^{56,58}$

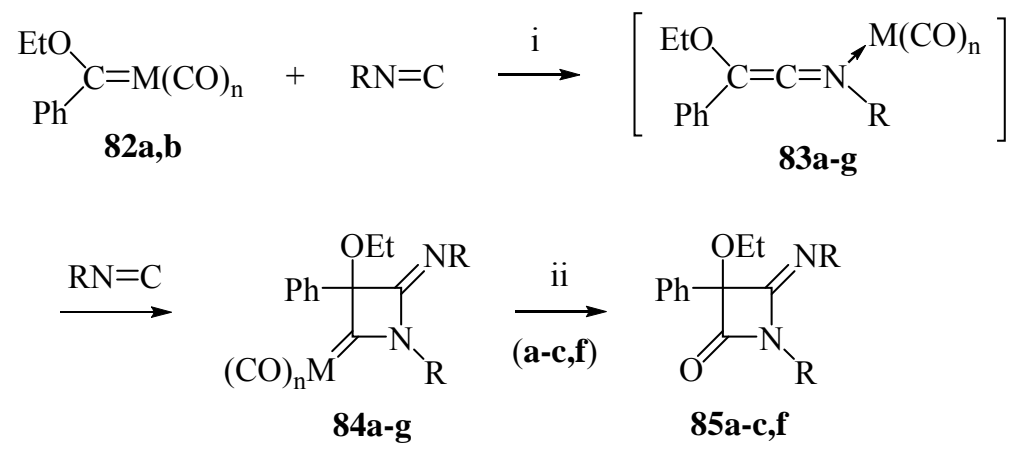

i: light petroleum, r. t. (for a-d,g) or hexane, $0{ }^{\circ} \mathrm{C}$ (for e,f)

ii: $\mathrm{KMnO}_{4}, \mathrm{H}_{2} \mathrm{O} / \mathrm{C}_{6} \mathrm{D}_{6}$, r. t. (for a-c) or pyridine $N$-oxide, toluene, $\Delta$ (for $\mathbf{f}$ )

\begin{tabular}{|c|c|c|c|c|c|c|c|}
\hline \multirow[b]{2}{*}{82} & \multirow[b]{2}{*}{ 83-85 } & \multicolumn{6}{|c|}{ Yield $(\%)^{\mathrm{c}}$} \\
\hline & & $\mathrm{M}$ & $\mathrm{n}$ & $\mathrm{R}$ & 84 & 85 & Other / Yield (\%) \\
\hline \multirow[t]{4}{*}{$\mathbf{a}$} & $\mathbf{a}$ & $\mathrm{Fe}$ & 4 & $\mathrm{Me}$ & 94 & 95 & \\
\hline & b & $\mathrm{Fe}$ & 4 & $\mathrm{Ph}$ & $96^{\mathrm{a}} / 76^{\mathrm{b}}$ & & \\
\hline & c & $\mathrm{Fe}$ & 4 & $c-\mathrm{C}_{6} \mathrm{H}_{11}$ & $94^{\mathrm{a}} / 77^{\mathrm{b}}$ & & \\
\hline & d & $\mathrm{Fe}$ & 4 & $\mathrm{CH}_{2} \mathrm{Ph}$ & $80^{\mathrm{b}}$ & & \\
\hline \multirow[t]{3}{*}{$\mathbf{b}$} & e & W & 5 & $\mathrm{CH}_{2} \mathrm{Ph}$ & 7 & & $\mathbf{8 6 a} / 10, \mathbf{8 7 a} / 14$ \\
\hline & f & $\mathrm{W}$ & 5 & $\mathrm{CH}=\mathrm{CH}_{2}$ & 20 & 88 & $(Z)-\mathbf{8 8 a} / 50,(E)-\mathbf{8 8 a} \mathbf{a} / 10$ \\
\hline & g & $\mathrm{W}$ & 5 & $\mathrm{CH}=\mathrm{CHR}$ & 31 & & $(Z)-\mathbf{8 8 b} / 52,(E)-\mathbf{8 8 b} / 10$ \\
\hline
\end{tabular}

${ }^{a}$ Ref. ${ }^{56}$ b ${ }^{\text {Ref. }}{ }^{51}$ c No yield figures for 85b,c (formed without side materials). ${ }^{56}$<smiles></smiles>

$\mathrm{PhCH}_{2} \mathrm{~N}=\mathrm{C}=\mathrm{W}(\mathrm{CO})_{5}$

87a

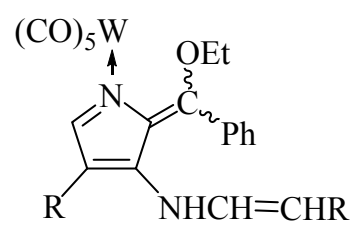

88a: $\mathrm{R}=\mathrm{H} \quad$ b: $\mathrm{R}=\mathrm{Me}$

\section{Scheme 19}

Further derivatives 84 could be prepared from the manganese complex 82c (Scheme 20). ${ }^{59}$ This species is less reactive towards isocyanides than the substrates 82a,b. Moreover, the excess isocyanide which is necessary for ring closure tends to displace the metal from the ketenimine complex $\mathbf{8 3}$ to leave a mixture of the isocyanide complex $\mathbf{8 7}$ and the free ketenimine $\mathbf{8 9}$. As a 
consequence of this competing process, the 'regular' products $\mathbf{8 4 h}-\mathbf{j}$ were accompanied by [2+2] cycloadducts like 90a-c; the proportions varied with the conditions and the kind of isocyanide. Since the conversion $\mathbf{8 3} \rightarrow \mathbf{8 4}$ proceeds more slowly than the step $\mathbf{8 2 c} \rightarrow \mathbf{8 3}$, it was also possible to construct azetidinylidene complexes $\mathbf{8 4}$ (including the type 90) from two different isocyanides; this is exemplified by the couples 84k / 90d and 84l / 90e. Representatives of both ring series such as $\mathbf{8 4 h}, \mathbf{i}$ and $\mathbf{9 0 a}, \mathbf{b}$ could be demetalated with permanganate salt to give the $\beta$ lactams 85a,b and 91a,b, respectively. ${ }^{59}$

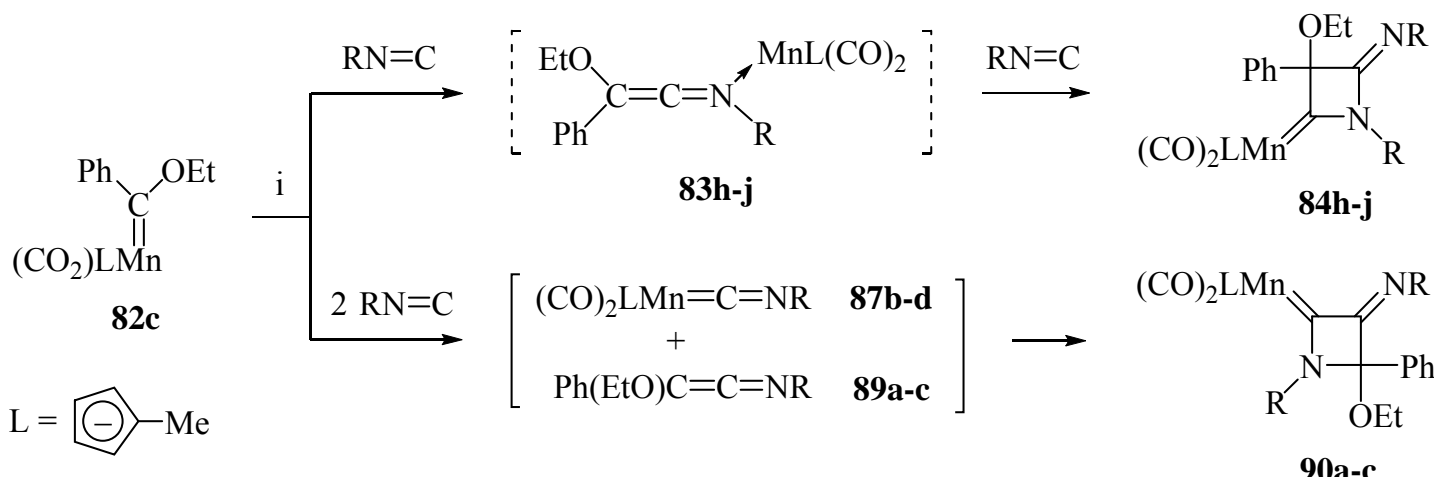

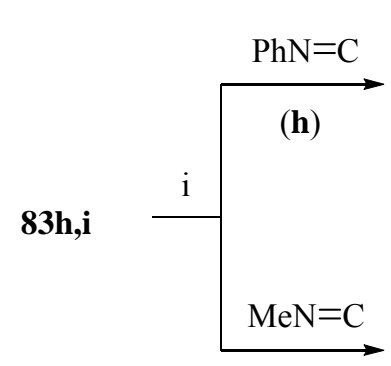

(i)<smiles>CCOC1(c2ccccc2)C(=N)N(C)C1=NC(=O)OC(C)=O</smiles><smiles>CCC1(c2ccccc2)C(=NC)C(=[N+](C)C(C)=O)N1c1ccccc1</smiles>

* from 87c $+89 a$ 90d *

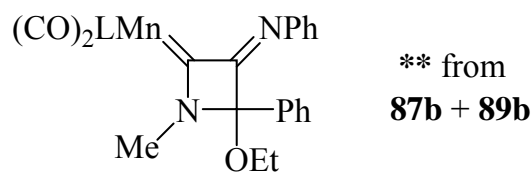
90e **<smiles>[R]N1C(=O)C([R])(c2ccccc2)C1=[W]</smiles>

85a,b $(E+Z)$

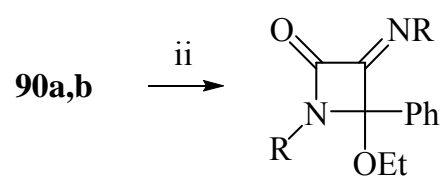

91a,b $(E+Z)$

i: toluene, $\Delta$ ii: $\mathrm{KMnO}_{4}$, diethyl ether $/ \mathrm{H}_{2} \mathrm{O}$, r. t.

\begin{tabular}{cccccc}
$\mathbf{8 3 , 8 4}$ & $\mathrm{R}$ & $\mathbf{8 7}$ & $\mathbf{8 9 - 9 1}$ & Yield (\%) 84 / 90 & Conditions \\
\hline $\mathbf{h}$ & $\mathrm{Me}$ & $\mathbf{b}$ & $\mathbf{a}$ & $30[4] / 15[25]$ & $60{ }^{\circ} \mathrm{C}(4 \mathrm{~h}) \rightarrow 100^{\circ} \mathrm{C}(3 \mathrm{~h})\left[100{ }^{\circ} \mathrm{C}(4 \mathrm{~h})\right]$ \\
i & $\mathrm{Ph}$ & $\mathbf{c}$ & $\mathbf{b}$ & $67[37] / 4[10]$ & $60{ }^{\circ} \mathrm{C}(4 \mathrm{~h}) \rightarrow 100^{\circ} \mathrm{C}(3 \mathrm{~h})\left[100{ }^{\circ} \mathrm{C}(4 \mathrm{~h})\right]$ \\
j & $\mathrm{CH}_{2} \mathrm{Ph}$ & $\mathbf{d}$ & $\mathbf{c}$ & $29 /$ trace & $100^{\circ} \mathrm{C}(3.5 \mathrm{~h})$
\end{tabular}

\section{Scheme 20}


In contrast to the ketenimine complexes 83a-j dealt with above, analogs prepared from the chromium complexes 82d,e did not undergo [1+3] cycloadditions with isocyanides (Scheme 21). After 83k,l have taken up methyl and phenyl isocyanide, respectively, cyclization engaged the $C$ and $\mathrm{N}$-attached aryl groups to give the indane-2,3-diimine $\mathbf{8 6} \mathbf{b}^{60}$ and - through hydrolysis of the enol ether - the 3-aminoindole 92. ${ }^{54,61}$ However, in the case of 4-nitrophenyl isocyanide, i.e. with the intermediary 1:1 adduct formed from 83m, generation of an indole is impeded because of the electron-withdrawal exerted by the nitro group; hence, a further isocyanide molecule will attack to eventually afford the azetidine-2,3-diimine 93 - formally a $[1+1+2]$ cycloadduct of two isocyanides and one ketenimine (for another rare example, $c f$. ref. $^{2}$ ).

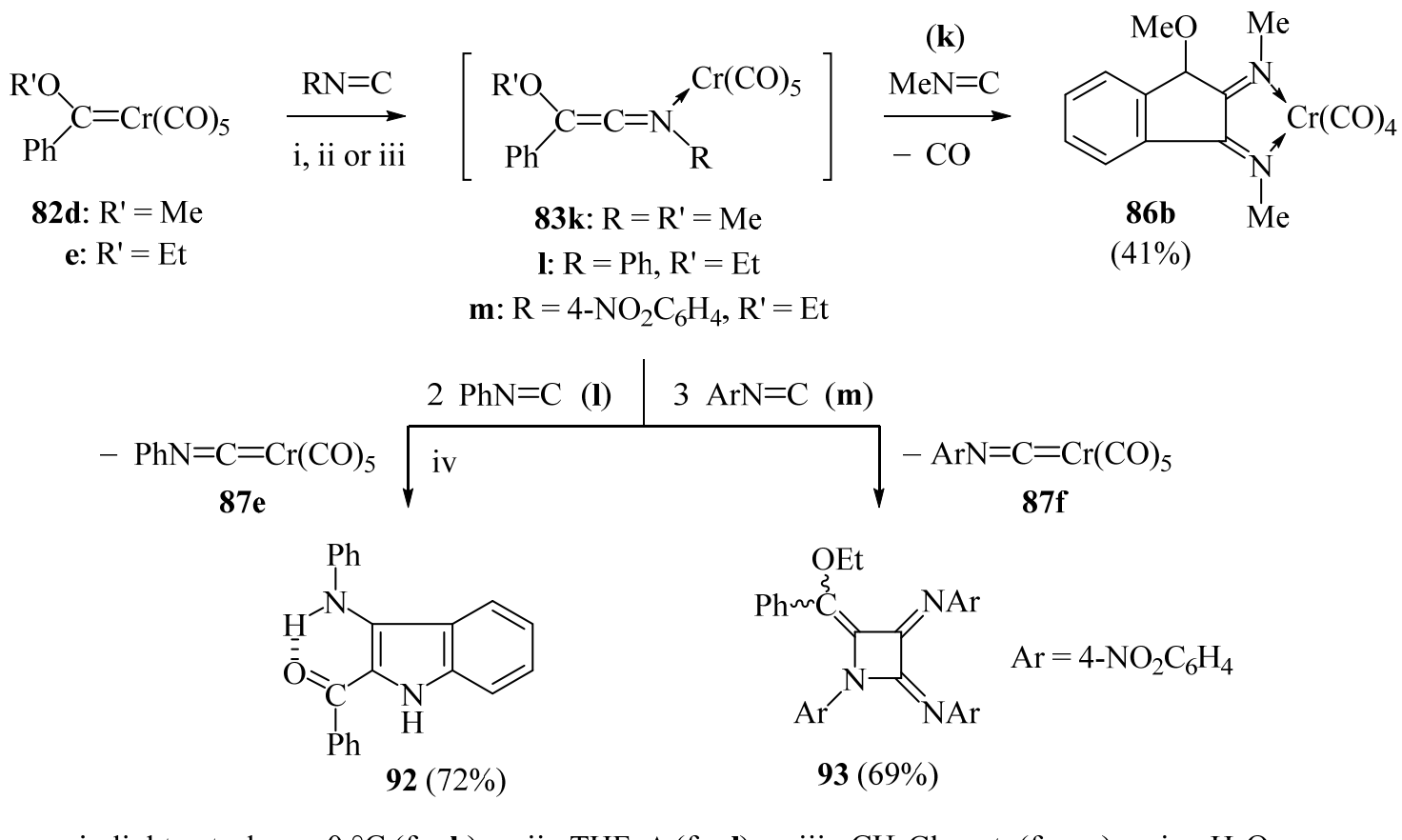

i: light petroleum, $0{ }^{\circ} \mathrm{C}$ (for k) ii: THF, $\Delta$ (for l) iii: $\mathrm{CH}_{2} \mathrm{Cl}_{2}$, r.t. (for m) iv: $\mathrm{H}_{2} \mathrm{O}$

\section{Scheme 21}

Addition of alkynes: a) Alk-1-ynes: Two types of 4-ylideneazetidin-2-ylidene complexes arise, when the second isocyanide that effects ring closure to 84 and 90 (cf. Scheme 19, 20) is replaced with a 1-unsubstituted alk-1-yne (94) (Scheme 22). Heating an equimolar mixture of 82b, cyclohexyl isocyanide, and (trimethylsilyl)ethyne (94a), the four-membered rings 95a and 97a were formed (isolated as the silicon-free derivatives $\mathbf{b}$ ). While the process leading to $\mathbf{9 5}$ can be compared to that giving $\mathbf{8 4}$, the formation of $\mathbf{9 7}$ resembles the route to series $\mathbf{9 0}$; the vinylidene complexes 96 - putative intermediates - may arise directly from 82b. Using alkynes like 94b,c, only the derivatives $\mathbf{9 7} \mathbf{c}, \mathbf{d}$ were found, with the $Z$ isomer predominating. ${ }^{62}$ 


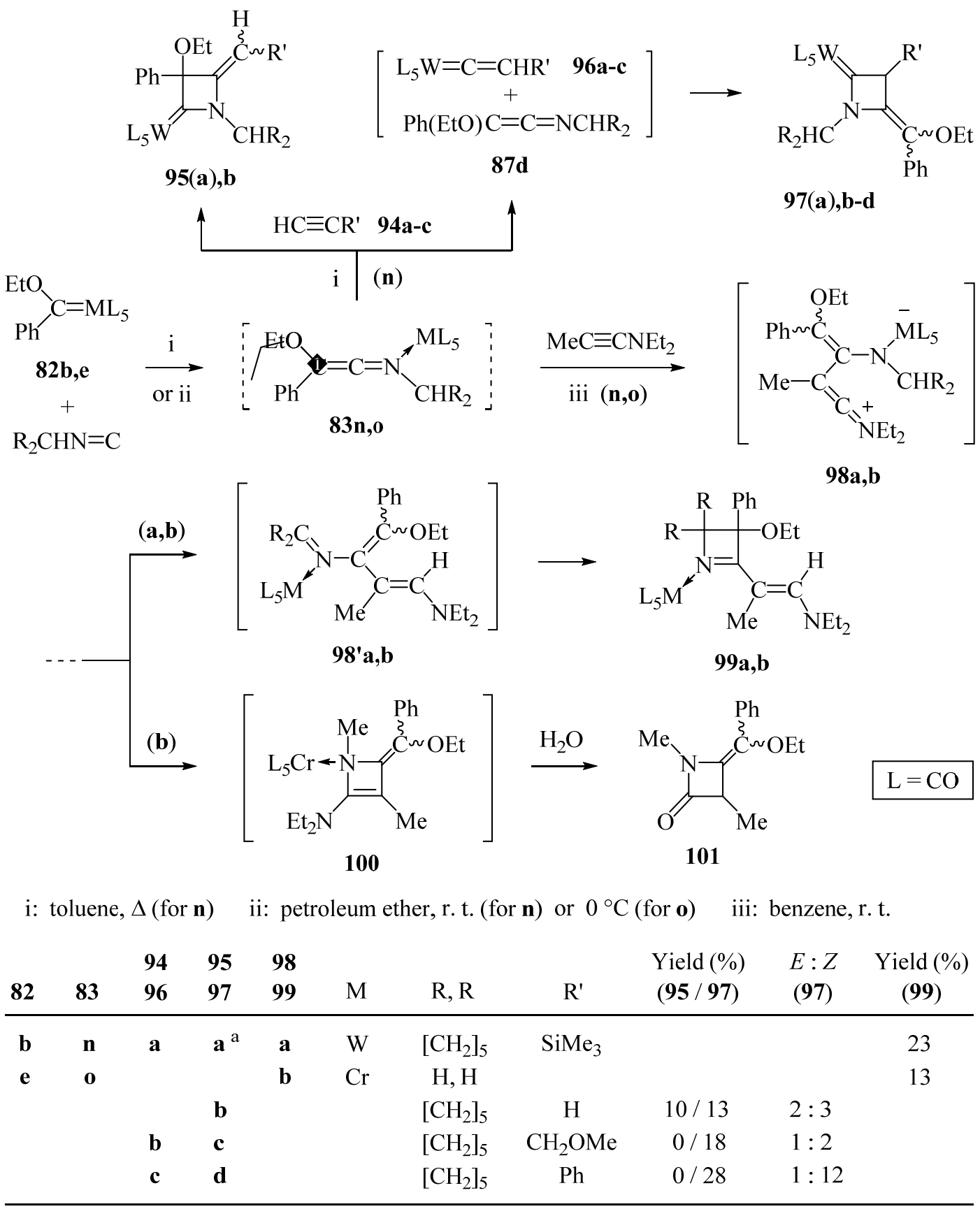

a Products 95a and 97a were hydrolyzed to 95b and 97b during work-up.

\section{Scheme 22}

b) Ynamines: The reaction of the ketenimine complexes 83 with the electron-rich diethyl(prop-1-ynyl)amine took an unexpected course: Treatment of 83n,o (isolated pure) furnished the 2,3-dihydroazete complexes 99a,b (Scheme 22). Here four atoms of the original ketenimine unit were incorporated into the product (the structure of $\mathbf{9 9 b}$ was studied by X-ray crystallography). 
Mechanistically, the reaction was understood as proceeding through an adduct of the type 98; in this species a hydrogen transfer from the $\mathrm{CHR}_{2}$ group to the central keteniminium carbon took place to generate the intermediate $\mathbf{9 8}$ ' which underwent electrocyclization. In the case of $\mathbf{9 8 \mathbf { b }}$, a second mode was operative, i.e. intramolecular [2+2] cycloaddition to the 1,4-dihydroazetidine complex 100 which on work-up was hydrolyzed to the $\beta$-lactam 101 (no yield). ${ }^{63}$

Ring contraction (Addendum): An unexpected formation of a four-membered ring was encountered when the [2+3] cycloadduct 102 from the ketenimine complex 83h (for prepration, see Scheme 20) and carbon disulfide was oxidized with aqueous permanganate (Scheme 23). Besides the regular product - the thiazolidin-5-one 103 - small amounts of the 3-iminothietane-2thione 104 were detected; formally, this material arose through ring contraction of 'deoxygenated' 103. Both compounds were formed in a $20: 1$ ratio with a total yield of $96 \%$ (crude). ${ }^{64}$

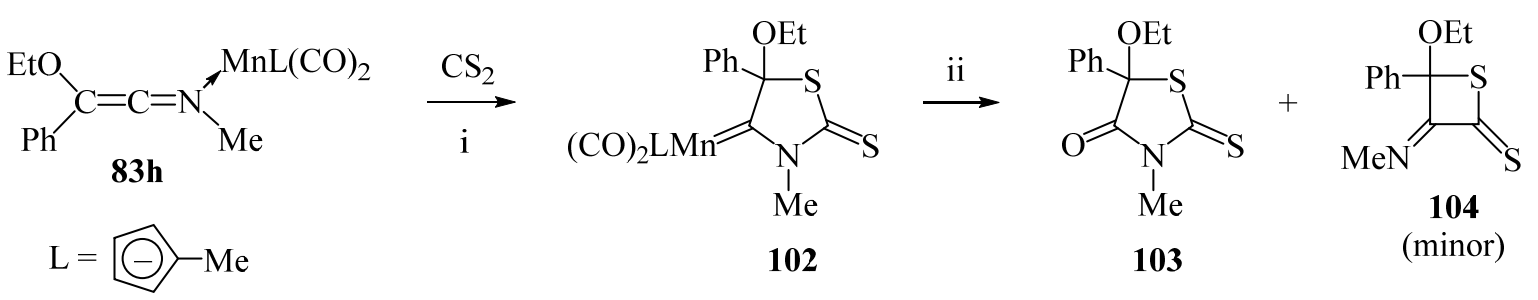

i: hexane, r. t. ii: $\mathrm{KMnO}_{4}$, diethyl ether $/ \mathrm{H}_{2} \mathrm{O}$, r.t.

\section{Scheme 23}

\subsection{Miscellaneous}

Functionalized phosphino(phosphonio)carbene: Treatment of the salt 105 with two equivalents of tert-butyl isocyanide gave rise to the 1,3-diphosphetanium ring as in $\mathbf{1 0 8}$ (no yield); employment of only one equivalent led to the recovery of $50 \%$ of the starting substrate (Scheme 24). ${ }^{65}$ The reaction commenced with formation of the ketenimine 106; but, while stable when unprotonated ( $c f$. ref. $^{66}$ ), this species rapidly inserts the second isocyanide into the $\mathrm{P}-\mathrm{H}$ bond to give an intermediate like 107 which underwent ring closure through elimination of diisopropylamine.

Butynedioic acid ester: It is known that reactions of isocyanides with dimethyl butynedioate (DMAD) do not follow the pattern of Section 2.1, i.e. giving cyclobutenediimines. ${ }^{2}$ However, a four-membered ring may arise from that reagent by another route. Indeed, a more recent study using cyclohexyl isocyanide has shown that - besides the cyclopenta[b]pyridine 109 (including minor quantities of an isomer and a 1-azaspiro[4.4]nonatriene) - the cyclohepta-anellated azetidinimine 110 was formed (Scheme 25). ${ }^{67,68}$ As a direct precursor the 3:1 cycloadduct of DMAD and the isocyanide, i.e. the cycloheptatrienimine 111, has been invoked. ${ }^{67}$ To rationalize its conversion into 110, a transient species like $\mathbf{1 1 2}$ is added here tentatively. Ensuing work of other 
authors concentrated on the preparation of $\mathbf{1 0 9}$ (including an X-ray study of the product); additional compounds were not reported. ${ }^{69}$

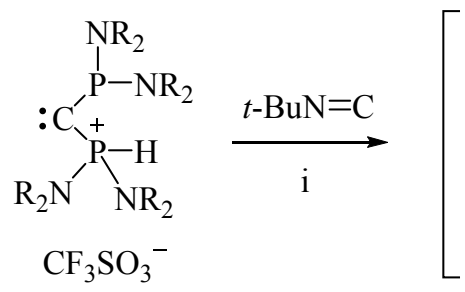

105

$$
\text { i: } \begin{gathered}
\mathrm{R}=i-\mathrm{Pr} \\
\mathrm{CH}_{2} \mathrm{Cl}_{2},-78^{\circ} \mathrm{C} \rightarrow \text { r. t. }
\end{gathered}
$$

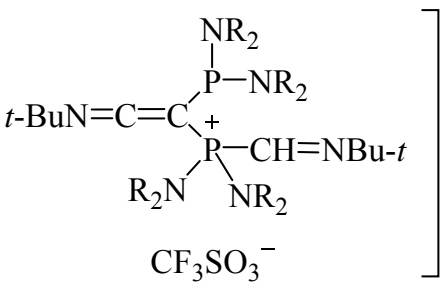

107

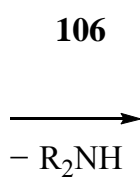

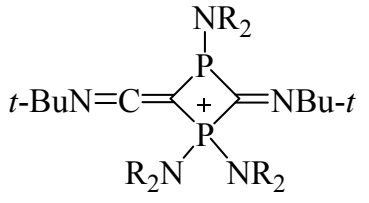

$\mathrm{CF}_{3} \mathrm{SO}_{3}^{-}$

108

\section{Scheme 24}<smiles>[R]N=C1C(=[18O])N([R])C2=C(F)C(F)=C(F)C2(F)C(F)=C1F</smiles>

$\mathrm{E}=\mathrm{CO}_{2} \mathrm{Me}$

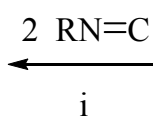

$3 \mathrm{MeO}_{2} \mathrm{CC} \equiv \mathrm{CCO}_{2} \mathrm{Me}$

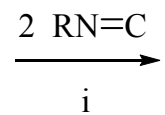

$\varkappa^{\prime} \mathrm{RN}=\mathrm{C}$<smiles></smiles>

111<smiles>[R]N1CCC2(C1=N)C(F)=C(F)C(F)=C(F)C2(F)F</smiles>

$112(?)$<smiles>[R]N=C1C2=C(F)C(F)=C(F)C(F)=C(F)C2(F)N1[R]</smiles>

$110(3 \%)$<smiles>C1COC1</smiles>

i: diethyl ether, $5-10{ }^{\circ} \mathrm{C} \rightarrow$ r. t.

\section{Scheme 25}

Oligosilanes: Insertion of isocyanides into the $\mathrm{Si}-\mathrm{Si}$ bond involving a unique skeletal rearrangement has been encountered when the tetrasilanes 113a-c and the hexasilane 113d were reacted with certain aryl isocyanides in the presence of a palladium catalyst and 1,1,3,3-tetramethylbutyl isocyanide (115) (Scheme 26). This procedure gave the 1,2,4-azadisiletanes 114a-g and 114h, respectively. ${ }^{70,71}$ The structures of $\mathbf{1 1 4} \mathbf{c}^{70}$ and $\mathbf{1 1 4 h} \mathbf{h}^{71}$ have been elucidated by X-ray crystallography. Regarding the tert-alkyl isocyanide 115, this additive, without entering the four-membered ring, has proved an effective promotor in most cases as evidenced by comparison of the yields. ${ }^{71}$ 


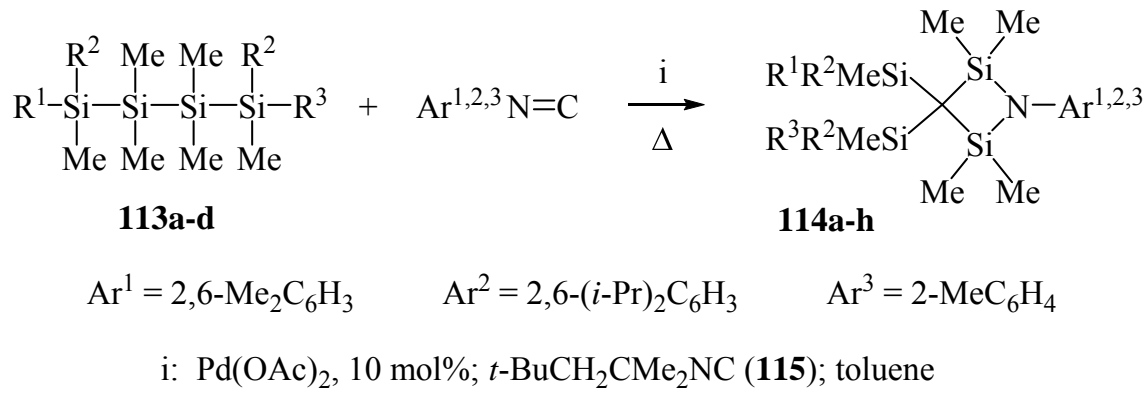

\begin{tabular}{ccccccc}
$\mathbf{1 1 3}$ & $\mathrm{R}^{1}$ & $\mathrm{R}^{2}$ & $\mathrm{R}^{3}$ & & $\mathbf{1 1 4}$ & Yield (\%) [115: yes /no ] \\
\hline a & $\mathrm{Me}$ & $\mathrm{Me}$ & $\mathrm{Me}$ & $\mathrm{Ar}^{1}$ & $\mathbf{a}$ & $40 / 9$ \\
& $\mathrm{Me}$ & $\mathrm{Me}$ & $\mathrm{Me}$ & $\mathrm{Ar}^{2}$ & $\mathbf{b}$ & $45 / 40$ \\
b & $\mathrm{Ph}$ & $\mathrm{Me}$ & $\mathrm{Ph}$ & $\mathrm{Ar}^{1}$ & $\mathbf{c}$ & $31 / 37$ \\
& $\mathrm{Ph}$ & $\mathrm{Me}$ & $\mathrm{Ph}$ & $\mathrm{Ar}^{2}$ & $\mathbf{d}$ & $62 / 50$ \\
& $\mathrm{Ph}$ & $\mathrm{Me}$ & $\mathrm{Ph}$ & $\mathrm{Ar}^{3}$ & $\mathbf{e}$ & $24 / 0$ \\
c & $\mathrm{Ph}$ & $\mathrm{Ph}$ & $\mathrm{Ph}$ & $\mathrm{Ar}^{1}$ & $\mathbf{f}$ & $28 / 10$ \\
& $\mathrm{Ph}$ & $\mathrm{Ph}$ & $\mathrm{Ph}$ & $\mathrm{Ar}^{2}$ & $\mathbf{g}$ & $48 / 54$ \\
d & $\mathrm{SiMe}_{2} \mathrm{SiMe}_{3}$ & $\mathrm{Me}$ & $\mathrm{Me}$ & $\mathrm{Ar}^{2}$ & $\mathbf{h}$ & $15 /-$
\end{tabular}

\section{Scheme 26}

Organoaluminum compounds: tert-Butyl isocyanide was found to undergo double insertion into one $\mathrm{Al}-\mathrm{C}$ bond of tris(tetramethylcyclopentadienyl)aluminum (116) to form the four-membered ring 117 (Scheme 27). The cyclic structure has been elucidated by X-ray diffraction. The strong Al-N linkage seems to be the driving force behind the twofold insertion which is favored to such an extent as to leave unreacted $\mathbf{1 1 6}$ when working with less than two equivalents of isocyanide. ${ }^{72}$

Insertion of isocyanides into the $\mathrm{Al}-\mathrm{Al}$ bond of the dialane 118 resulted in the formation of a three- or four-membered ring, depending on the reagent and conditions. Using one equivalent of tert-butyl isocyanide, compound 119a was obtained as the single product. However, phenyl isocyanide not only afforded the expected derivative 119b, but also gave $17 \%$ of the product of double insertion, i.e. the bicyclic system 120. Hence, on repeating the experiment with two equivalents of this isocyanide, compound $\mathbf{1 2 0}$ was isolated exclusively. An analogous run with tertbutyl isocyanide was not reported. ${ }^{73}$

The aluminum(I) complex 121 (dealt with in this section for practical reasons) was found to react very readily with two equivalents of 2,6-diisopropylphenyl isocyanide. When this reagent was added neat to a suspension of $\mathbf{1 2 1}$ in a minimum amount of solvent, the remarkable compound 122 was isolated. Its formation was thought to proceed through consecutive coupling of both isocyanides leaving a four-membered ring, the carbenic $\mathrm{C}(4)$ of which interfered with the adjacent isopropyl group to give the stable product 122. When working in a dilute medium, compound 123 arose, possibly via insertion of the two isocyanides into one of the $\mathrm{Al}-\mathrm{C}$ bonds to be followed by a skeletal rearrangement of the resultant eight-membered ring. The structures of 122 and 123 have been determined by X-ray crystallography. ${ }^{74}$ 


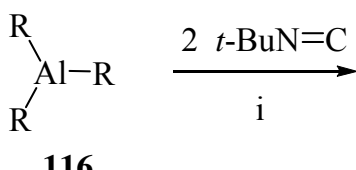

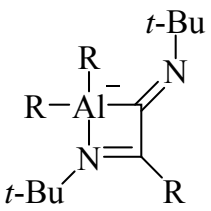<smiles>[R]C1C(C)=C(C)C(C)=C1C</smiles>

$117(56 \%)$

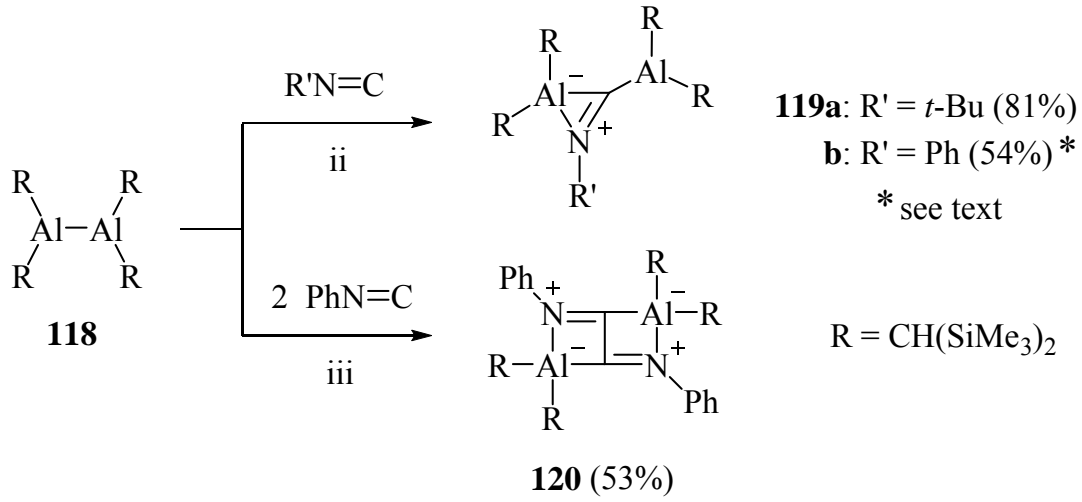

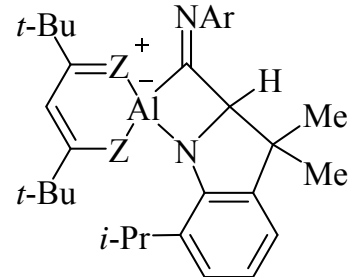

122: $Z=N A r(72 \%)$

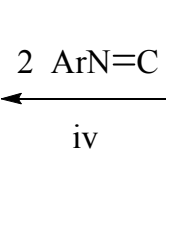

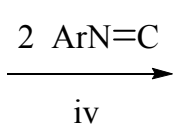

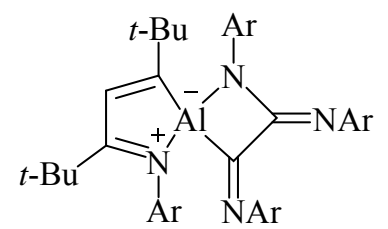

$123(61 \%)$

i: toluene, $-78^{\circ} \mathrm{C} \rightarrow$ r. t. $\quad$ ii: $n$-pentane, $-25^{\circ} \mathrm{C} \rightarrow$ r. t. $\quad$ iii: $n$-pentane, $-10^{\circ} \mathrm{C} \rightarrow$ r. t. iv: toluene, r. t. (see text)

\section{Scheme 27}

(Diaminoboryl)silanes: Insertion of an aryl isocyanide into the $\mathrm{Si}-\mathrm{B}$ bond of the borylsilanes 124 generates (boryl)(silyl)iminomethanes (125) (Scheme 28). Compounds of this type, e.g. 125a $\left(\mathrm{R}=\mathrm{Me}, \mathrm{Ar}=3,5-\mathrm{Me}_{2} \mathrm{C}_{6} \mathrm{H}_{3}\right)$, are obtained in high yield when working at room temperature. However, in refluxing toluene an unexpected rearrangement took place, consisting in a 1,2-shift of the silyl group to leave an (amino)(boryl)carbene species which engaged an adjacent isopropyl group to form the 1,2-azaboretidine 126a. ${ }^{75}$ The reaction was shown to be limited to isocyanides having a free ortho-position. Thus, while the reaction of 124a with 2,6-dimethylphenyl isocyanide even at $110^{\circ} \mathrm{C}$ did not go beyond the stage of insertion (125), four-membered rings like 126b-d were formed readily from a range of 2-alkynylphenyl isocyanides. Extending the experiments to 1,2-diisocyanobenzenes, only one $-\mathrm{N}=\mathrm{C}$ group reacted with the substrate to give the benzimidazolyl substituted azaboretidines 127a-c; the two derivatives a,b having $\mathrm{R}^{\prime \prime}=\mathrm{H}$ were obtained at room temperature. X-ray crystallographic data are available for the products 126d and 127a. ${ }^{75}$ 
Tris(trimethylsilyl)silyllithium: The silyllithium substrate $\mathbf{1 2 8}$ was found to react smoothly with two molecules of 2,6-dimethylphenyl isocyanide to form, in the presence of $N, N, N^{\prime}, N^{\prime}$-tetramethylethylenediamine (tmeda), the 1,2-dihydro-1,2-azasilete derivative 129 (Scheme 29). ${ }^{76}$ The process assumedly started with the formation of a lithioaldimine followed by migration of one silyl group to generate a silene species which incorporated the second isocyanide via electrocyclization. Quenching of $\mathbf{1 2 9}$ with trimethylsilyl triflate afforded the derivate $\mathbf{1 3 0},{ }^{76}$ while treatment with cyclopentadiene yielded the conjugated acid $131 .{ }^{77}$ Moreover, reacting 128 in the presence of the soft 1,2-bis(dimethylphosphino)ethane gave a product $\mathbf{1 2 9}$ having THF instead of tmeda. ${ }^{77}$ Detailed X-ray diffraction studies have been conducted with both $\mathbf{1 2 9}$ and $\mathbf{1 3 1} .^{76,77}$

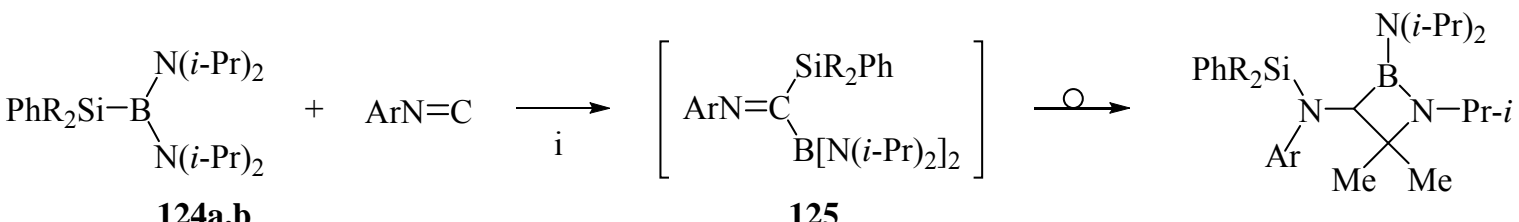

124a,b

125

126a-d

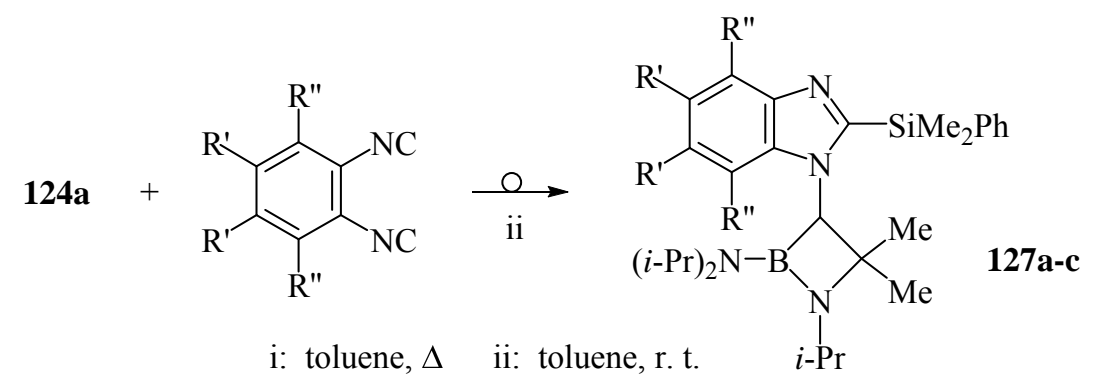

\begin{tabular}{|c|c|c|c|c|c|c|c|c|}
\hline \multirow[b]{2}{*}{124} & \multirow[b]{2}{*}{126} & \multirow[b]{2}{*}{127} & \multirow[b]{2}{*}{$\mathrm{R}$} & \multirow[b]{2}{*}{$\mathrm{R}^{\prime}$} & \multirow[b]{2}{*}{$\mathrm{R}^{\prime \prime}$} & \multirow[b]{2}{*}{$\mathrm{Ar}$} & \multicolumn{2}{|c|}{ Yield (\%) } \\
\hline & & & & & & & 126 & 127 \\
\hline \multirow[t]{3}{*}{$\mathbf{a}$} & $\mathbf{a}$ & $\mathbf{a}$ & $\mathrm{Me}$ & $\mathrm{H}$ & $\mathrm{H}$ & 3,5- $\mathrm{Me}_{2} \mathrm{C}_{6} \mathrm{H}_{3}$ & 76 & $71^{\mathrm{a}}$ \\
\hline & b & $\mathbf{b}$ & $\mathrm{Me}$ & $\mathrm{Me}$ & $\mathrm{H}$ & $2-\left(\mathrm{Me}_{3} \mathrm{SiC} \equiv \mathrm{C}\right) \mathrm{C}_{6} \mathrm{H}_{4}$ & 86 & $54^{\mathrm{a}}$ \\
\hline & c & c & $\mathrm{Me}$ & $\mathrm{H}$ & $\mathrm{Me}$ & $2-(t-B u C \equiv C) \mathrm{C}_{6} \mathrm{H}_{4}$ & 82 & \\
\hline b & d & & $\mathrm{Ph}$ & & & $2-\left(\mathrm{Me}_{3} \mathrm{SiC} \equiv \mathrm{C}\right) \mathrm{C}_{6} \mathrm{H}_{4}$ & 84 & \\
\hline
\end{tabular}

a Adduct with $\mathrm{BH}_{3}$.

\section{Scheme 28}

Dilithium tert-butylarsinide and -phosphinide: Action of the arsenic compound 132a on cyclohexyl isocyanide caused trimerization of the latter to form the product $\mathbf{1 3 3}$ which was isolated after addition of cyclohexane and diglyme (Scheme 30). By contrast, usage of the phosphorus analog 133b led to an engagement of six equivalents of the isocyanide to generate the more complicated structure 134 and, as a side product, an open-chain material originating from cyclohexylnitrene. The constitution of both cyclic products has been established by X-ray analyses. ${ }^{78}$ 


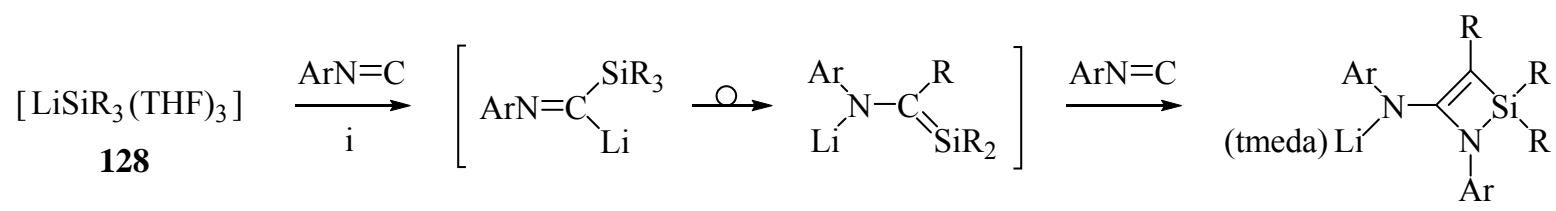<smiles>[Y19]C1=C([R])[Si]([R])([R])N1[Y8]</smiles>

$130(75 \%)$

$\mathrm{Ar}=2,6-\mathrm{Me}_{2} \mathrm{C}_{6} \mathrm{H}_{3}$ tmeda $=\mathrm{Me}_{2} \mathrm{~N}\left[\mathrm{CH}_{2}\right]_{2} \mathrm{NMe}_{2}$<smiles>[R][R]n1c([R])c([Al]N)n1[Al]</smiles>

$131(68 \%)$

i: pentane, tmeda, $-80^{\circ} \mathrm{C} \rightarrow$ r. t. $\quad$ ii: pentane, $-40^{\circ} \mathrm{C} \rightarrow$ r. t. $\quad$ iii: pentane, $-60^{\circ} \mathrm{C} \rightarrow$ r. t.

\section{Scheme 29}

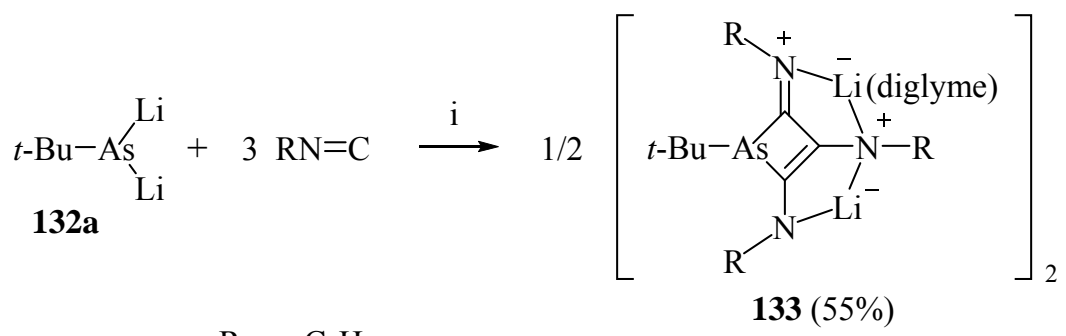

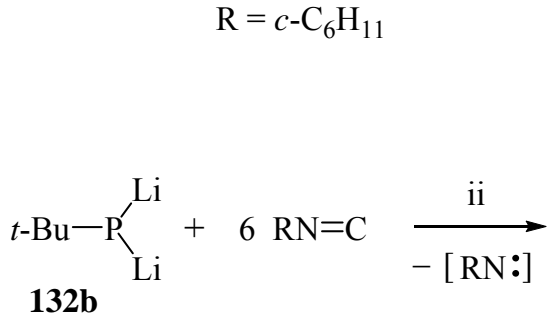

132b

i: $\mathrm{THF}, 20^{\circ} \mathrm{C}$; then diglyme/c-hexane

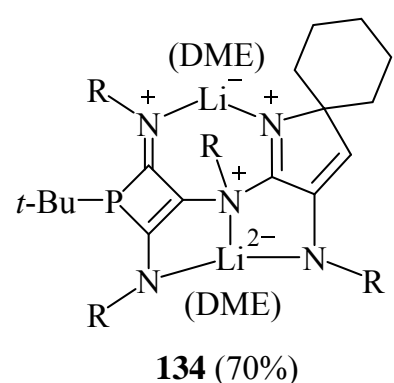

ii: $\mathrm{THF}, 20^{\circ} \mathrm{C}$; then DME

\section{Scheme 30}

Tetragermabutadiene: Studies on the behavior towards the heavy chalcogens selenium and tellurium have revealed that the title substrate 135 (Scheme 31) is capable of undergoing [1+4] cycloadditions or Ge-Ge bond scissions, depending on the reagents. The former mode was followed by selenium, whereas treatment with tellurium caused fragmentation of the substrate. In this context the reaction with 2-methoxyphenyl isocyanide was probed too, showing that one $\mathrm{Ge}-\mathrm{Ge}$ bond was broken: while the extruded germylene dimerized, the residual $\mathrm{Ge}_{3}$ chain cyclized to the 1,4-dihydrotrigermet-4-imine 136 which was characterized by X-ray crystallography. ${ }^{79}$ 


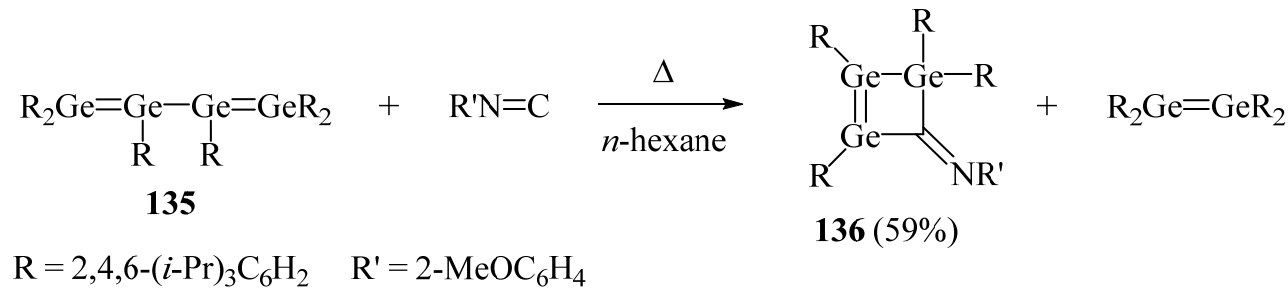

\section{Scheme 31}

\section{Reaction of isocyanides with cyclic substrates}

\subsection{Insertion of isocyanides into three-membered rings}

Triafulvenes: In a fashion similar to the behavior of cyclopropenones towards isocyanides, ${ }^{2}$ the triafulvenes 137a-c underwent ring expansion to the 2-ylidenecyclobutenimines 138a-h when treated with the respective isocyanides in an aprotic medium (Scheme 32). ${ }^{80}$

From the substrates 137d,e, however, four-membered rings such as $\mathbf{1 3 8 i - m}$ could not be obtained. In this instance two equivalents of the isocyanide were engaged to afford, depending on the substituents $\mathrm{R}^{1}, \mathrm{R}^{2}$, and $\mathrm{R}^{3}$, (i) the cyclopentenediimine 139 or the azapentalenes $\mathbf{1 4 0 \mathbf { a } , \mathbf { b }}$ (which were formed through intramolecular dehydrogenation of a precursor like 139 having $\mathrm{CH}_{2} \mathrm{Ph}$ and $\mathrm{CH}_{2} \mathrm{CO}_{2} \mathrm{Et}$ instead of $t-\mathrm{Bu}$ ), and (ii) the furo[b]pyridine derivatives 141a,b when reacting the benzoyl-containing triafulvene $\mathbf{1 3 7 e .}$

Cyclopropenylioborates: Studies on this class ${ }^{81}$ led to the discovery of another insertion of an isocyanide into a cyclopropene ring (Scheme 33): Compound 143 - easily prepared from $142^{82}$ or its product of hydrolysis (144) reacted with tert-butyl isocyanide to give the cyclobutenimine 145 in good or reasonable yield. The molecular geometry was determined by X-ray diffraction. ${ }^{83}$

Cyclopropanedicarboxylic acid esters: A lanthanide-catalyzed insertion of aryl isocyanides into bis-acceptor activated cyclopropanes like $\mathbf{1 4 6}$ has been reported to lead directly to the cyclopentene derivatives 148 (Scheme 34). Substrates devoid of the $\operatorname{Ar}^{1}$ ligand (which functions as an additional activator) failed to react. The conversion was viewed as proceeding via fourmembered rings like 147, but these species could not be observed for their high proclivity to insert an isocyanide themselves (as exemplified for $\mathrm{Ar}^{1}=\mathrm{Ph} / \mathrm{Ar}^{2}=4-\mathrm{MeOC}_{6} \mathrm{H}_{4}$ ) ${ }^{84}$ Hence, the reaction of 146 parallels the behavior of oxiranes, ${ }^{85}$ viz. the occurrence of double isocyanide insertion, with the failure to detect a four-membered ring, ${ }^{85}$ which belies the quotation made in ref. $^{84}$. 
<smiles>[R]C([R4])=C1C(=[W])C(c2ccccc2)=C1[R]</smiles>

138a-h

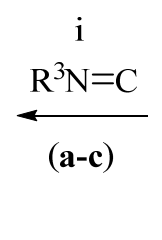

137a-e

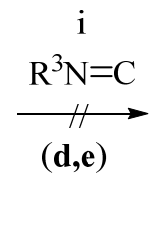

$\underset{(\mathbf{d}, \mathbf{e})}{\stackrel{\mathrm{M}}{\longrightarrow}}$<smiles>[R]C([R4])=C1C(=[18N])C(c2ccccc2)=C1[R]</smiles>

138i-m

i: $\mathrm{MeCN}, \Delta$

\begin{tabular}{|c|c|c|c|c|c|c|c|c|c|c|}
\hline 137 & 138 & 140 & 141 & $\mathrm{R}^{1}$ & $\mathrm{R}^{2}$ & $\mathrm{R}^{3}$ & Yield (\%): 138 & 139 & 140 & 141 \\
\hline \multirow[t]{3}{*}{$\mathbf{a}$} & $\mathbf{a}$ & & & $\mathrm{COMe}$ & $\mathrm{COMe}$ & $c-\mathrm{C}_{6} \mathrm{H}_{11}$ & 64 & & & \\
\hline & b & & & COMe & $\mathrm{COMe}$ & $\mathrm{PhCH}_{2}$ & 56 & & & \\
\hline & c & & & COMe & $\mathrm{COMe}$ & $\mathrm{EtO}_{2} \mathrm{CCH}_{2}$ & 47 & & & \\
\hline \multirow[t]{3}{*}{$\mathbf{b}$} & d & & & $\mathrm{COPh}$ & $\mathrm{COPh}$ & $c-\mathrm{C}_{6} \mathrm{H}_{11}$ & 64 & & & \\
\hline & $\mathbf{e}$ & & & $\mathrm{COPh}$ & $\mathrm{COPh}$ & $\mathrm{PhCH}_{2}$ & 76 & & & \\
\hline & f & & & $\mathrm{COPh}$ & $\mathrm{COPh}$ & $\mathrm{TsCH}_{2}$ & 69 & & & \\
\hline \multirow[t]{2}{*}{ c } & g & & & $\mathrm{CN}$ & $\mathrm{Ph}$ & $t$-Bu & 42 & & & \\
\hline & $\mathbf{h}$ & & & $\mathrm{CN}$ & $\mathrm{Ph}$ & $c-\mathrm{C}_{6} \mathrm{H}_{11}$ & 63 & & & \\
\hline \multirow[t]{3}{*}{ d } & $\mathbf{i}$ & & & $\mathrm{CN}$ & $\mathrm{CN}$ & $t$-Bu & 0 & 81 & & \\
\hline & $\mathbf{j}$ & $\mathbf{a}$ & & $\mathrm{CN}$ & $\mathrm{CN}$ & $\mathrm{PhCH}_{2}$ & 0 & & 58 & \\
\hline & $\mathbf{k}$ & $\mathbf{b}$ & & $\mathrm{CN}$ & $\mathrm{CN}$ & $\mathrm{EtO}_{2} \mathrm{CCH}_{2}$ & 0 & & 43 & \\
\hline \multirow[t]{2}{*}{ e } & 1 & & $\mathbf{a}$ & $\mathrm{CN}$ & $\mathrm{COPh}$ & $c-\mathrm{C}_{6} \mathrm{H}_{11}$ & 0 & & & 65 \\
\hline & $\mathbf{m}$ & & b & $\mathrm{CN}$ & $\mathrm{COPh}$ & $\mathrm{PhCH}_{2}$ & 0 & & & 50 \\
\hline
\end{tabular}

\section{Scheme 32}

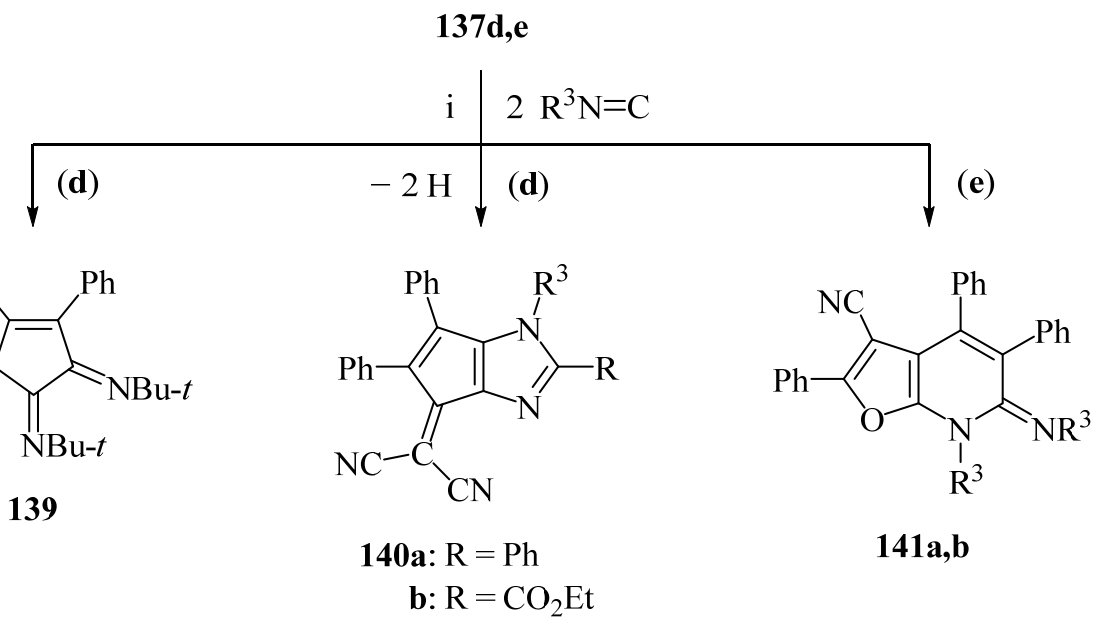




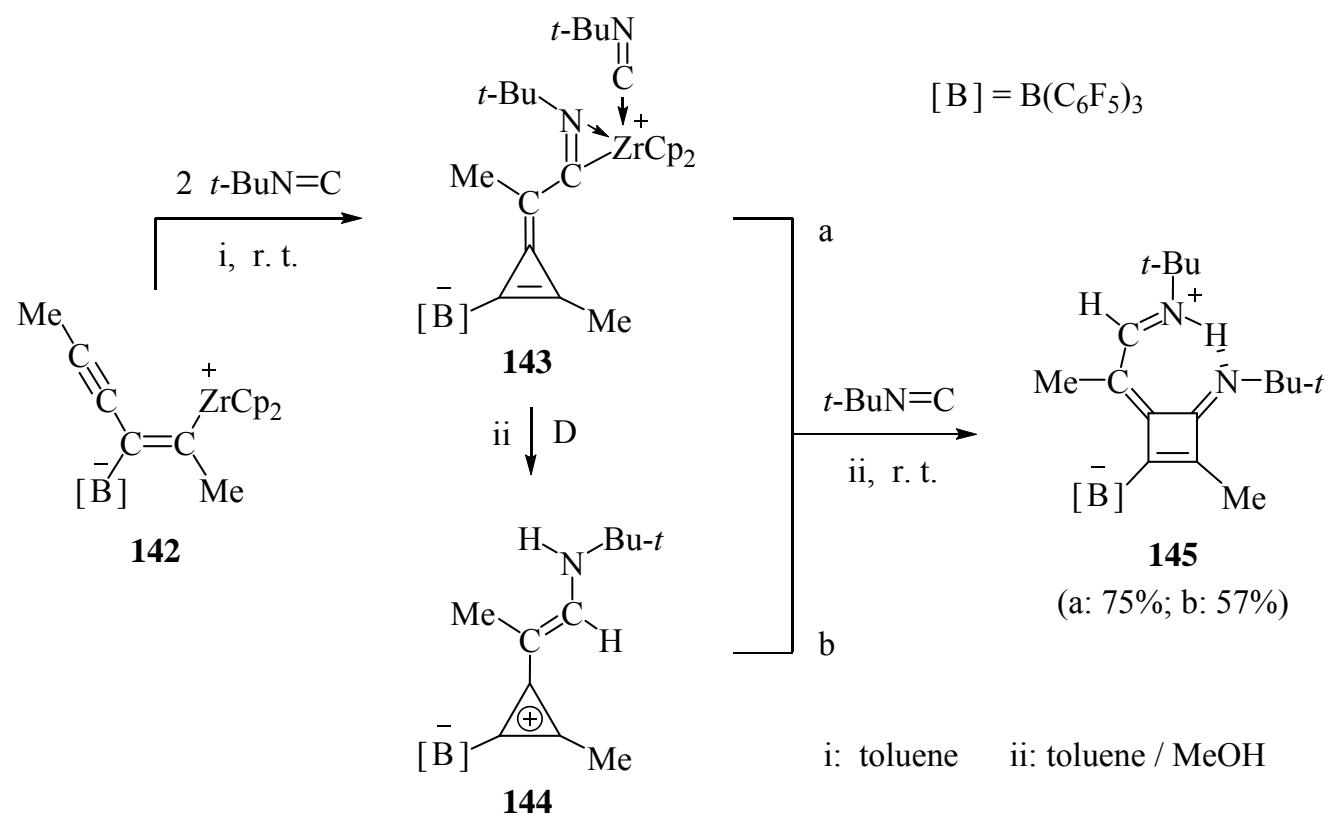

\section{Scheme 33}

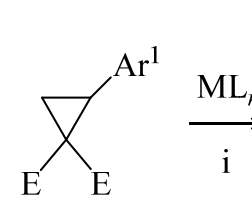

146
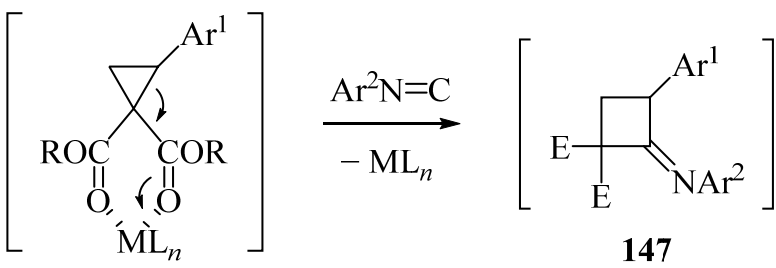

147

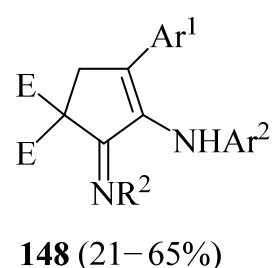

$148(21-65 \%)$

$$
\mathrm{E}=\mathrm{CO}_{2} \mathrm{Me} / \mathrm{Et} \quad \mathrm{ML}_{n}=\operatorname{Pr}\left(\mathrm{CF}_{3} \mathrm{SO}_{3}\right)_{3}(20 \mathrm{~mol} \%) \quad \mathrm{i}: \mathrm{ClCH}_{2} \mathrm{CH}_{2} \mathrm{Cl}, \Delta
$$

$\mathrm{Ar}^{1}=\mathrm{Ph}, 4-\mathrm{Me} / \mathrm{MeOC}_{6} \mathrm{H}_{4}, 2$-furyl/-thienyl $\quad \mathrm{Ar}^{2}=4-\mathrm{MeO} / \mathrm{MeSC}_{6} \mathrm{H}_{4}, 3-\mathrm{Cl}-4-\mathrm{MeOC}_{6} \mathrm{H}_{3}$

\section{Scheme 34}

1H-Aluminirene: tert-Butyl isocyanide was found to insert under very mild conditions into the aluminirene unit of the spiro substrate 149 to form the unique molecule 150. Of this compound stable $E$ and $Z$ isomers were detected by NMR spectroscopy. Crystallization gave a solid in $57 \%$ yield that, according to $X$-ray diffraction, represented the $Z$ configured form. It may be added by analogy that carbon monoxide transformed 149 into the corresponding aluminetimine. ${ }^{86}$ 
<smiles>Cc1cc(C)[n+]([Al])c([As])c1[As]C(C)C</smiles>

149

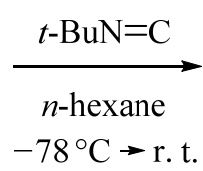

$\mathrm{Ar}=2,6-(i-\mathrm{Pr})_{2} \mathrm{C}_{6} \mathrm{H}_{3}$

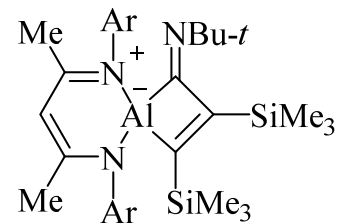

(E)- and (Z)-150 (see text)

\section{Scheme 35}

$\alpha$-Lactams: The conversion of this class into imino-substituted $\beta$-lactams through reaction with isocyanides is well established. ${ }^{2}$ In a more recent work a stereochemical aspect was investigated (Scheme 36) ${ }^{87}$ Heating the enantiomer $(R)$-151 with tert-butyl isocyanide gave rise to a $\beta$-lactam like $\left(E, R^{*}\right)-153$ of unknown absolute configuration (low enantiomeric excess), i.e. the stereochemical information got almost lost (if not fully). This was rationalized by considering the behavior of the zwitterionic intermediate $(R)$-152: this species, formed with inversion at $\mathrm{C}(3)$, did not cyclize directly [which must have led to $(E, R)-153$ ], but in a competing step it underwent a $1 / \rightarrow 3 /$ hydrogen shift to generate the ketenimine 154 which would yield racemic $(E)-153$.<smiles>O=C1[C@@H](Br)[C@@H]1Br</smiles>

$(R)-151$

i: neat, $100^{\circ} \mathrm{C}$, $10^{-3}$ Torr
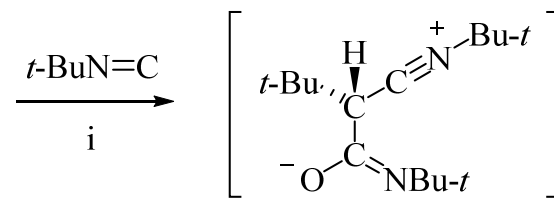

$(R)-152$

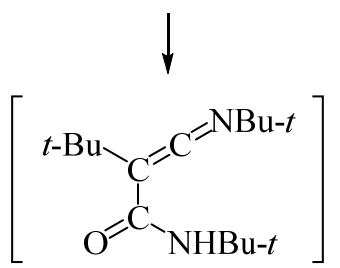

154

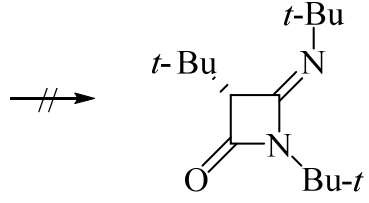

$(E, R)-\mathbf{1 5 3}$

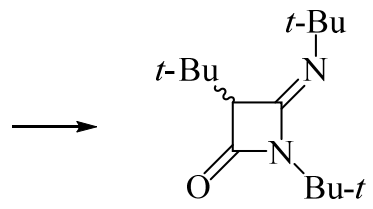

$\left(E, R^{*}\right)-\mathbf{1 5 3}(69 \%)$

$[10 \% \mathrm{e} / \mathrm{e}]$

\section{Scheme 36}

Siliranes: The insertion of isocyanides into siliranes was found to affect the $\mathrm{Si}-\mathrm{C}$ bond. The first known examples originated from experiments with substrates like 155a-c and aryl isocyanides which gave the siletan-2-imines 156a-c (Scheme 37). Of these products the derivative 156b has been studied by $\mathrm{X}$-ray diffraction, showing a practically planar four-membered ring with elongated $\mathrm{Si}-\mathrm{C}$ and $\mathrm{C}-\mathrm{C}$ bonds and a $\mathrm{Z}$ configured imine function. ${ }^{88}$ Soon thereafter other authors ${ }^{89}$ investigated regioselectivity and stereospecificity: (i) Studying the behavior of the monosubstituted 
siliranes 155d-f towards tert-butyl isocyanide, they found that insertion occurred at the more substituted $\mathrm{Si}-\mathrm{C}$ bond ( $\rightarrow$ 156d-f), but this regioselectivity was gradually eroded as the substituent $\mathrm{R}^{1}$ became bulkier. (ii) Reactions of cis- and trans-155g with $p$-tolyl and tert-butyl isocyanide revealed that the formation of the respective siletan-2-imines $\mathbf{1 5 6 g}$,h proceeded with stereospecific retention of configuration. As for the reactivity of these compounds, it was observed inter alia that both cis- and trans-156g,h tautomerize to 2-amino-1,4-dihydrosiletes on heating. ${ }^{89}$

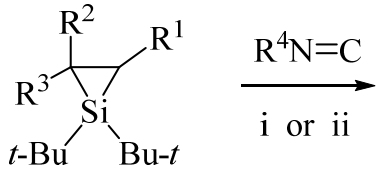

155a-f

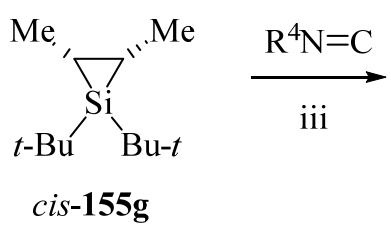

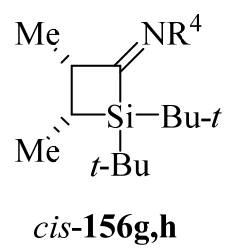<smiles>[R]C1C(=[W])[Si](Br)(Br)C1([R])[R]</smiles>

156a-f

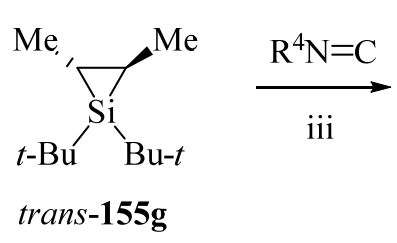

i: r. t. (solvent unreported) (for a-c) ii: benzene, $\Delta$ (for $\mathbf{d - f}$ ) iii: benzene, r. t. (for $\mathbf{g}$ ) or $\Delta$ (for $\mathbf{h})$

\begin{tabular}{|c|c|c|c|c|c|c|}
\hline 155,156 & $\mathrm{R}^{1}$ & $\mathrm{R}^{2}$ & $\mathrm{R}^{3}$ & $\mathrm{R}^{4}$ & Yield (\%) & Regioselectivity $^{\mathrm{b}}$ \\
\hline $\mathbf{a}$ & & $\mathrm{Me}$ & $\mathrm{Me}$ & $\mathrm{Ph}$ & 55 & \\
\hline b & $\mathbb{Z}$ & & $\mathrm{H}$ & $\mathrm{Ph}$ & 42 & \\
\hline c & $-[\mathrm{C}$ & $3^{-}$ & $\mathrm{H}$ & $4-\mathrm{NO}_{2} \mathrm{C}_{6} \mathrm{H}_{4}$ & 34 & \\
\hline d & $n$-Bu & $\mathrm{H}$ & $\mathrm{H}$ & $t-\mathrm{Bu}$ & $94^{\mathrm{a}}$ & $>95 / 5$ \\
\hline $\mathbf{e}$ & $i-\operatorname{Pr}$ & $\mathrm{H}$ & $\mathrm{H}$ & $t$-Bu & $98^{\mathrm{a}}$ & $92 / 8$ \\
\hline $\mathbf{f}$ & $t$-Bu & $\mathrm{H}$ & $\mathrm{H}$ & $t$-Bu & $97^{\mathrm{a}}$ & $86 / 14$ \\
\hline$c i s-\mathbf{g}^{\mathrm{c}}$ & & & & $4-\mathrm{MeC}_{6} \mathrm{H}_{4}$ & 96 & \\
\hline trans $-\mathrm{g}^{\mathrm{c}}$ & & & & $4-\mathrm{MeC}_{6} \mathrm{H}_{4}$ & 86 & \\
\hline$c i s-\mathbf{h}^{\mathrm{c}}$ & & & & $t$-Bu & 99 & \\
\hline $\operatorname{trans}^{-\mathbf{h}^{\mathrm{c}}}$ & & & & $t$-Bu & 98 & \\
\hline
\end{tabular}

${ }^{a}$ Yields refer to isolated products. ${ }^{b}$ By ${ }^{1} \mathrm{H}$ NMR spectroscopy. ${ }^{\mathrm{c}}$ One diastereoisomer by ${ }^{1} \mathrm{H}$ NMR spectroscopy.

\section{Scheme 37}

Thiirene S-oxides: Isocyanide insertion into the thiirene half-ring of $\mathbf{1 5 7}$ has been accomplished with 4-nitrophenyl isocyanide (Scheme 38). ${ }^{90}$ However, as observed with the cyclopropane derivative 146 (cf. Scheme 34), the reaction did not stop at the four-membered ring (158), but proceeded with double insertion to give a thiophenediimine 159 which, depending on the conditions, 
was obtained as $S$-oxide $(\mathrm{n}=1)$ or deoxygenated $(\mathrm{n}=0)$. Since four equivalents of the isocyanide were applied in both experiments, it is open whether 158 constitutes an elusive species.

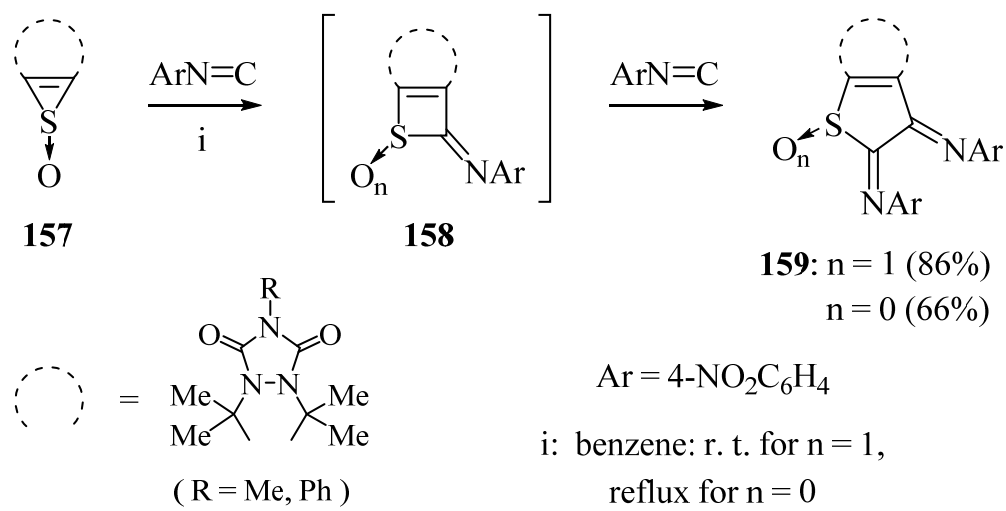

\section{Scheme 38}

Azoniaboranuidacyclopropane: The title substrate 160 was found to react readily with tosyl and benzyl isocyanide to give in excellent yield the 1-azonia-3-boranuidacyclobutanimines 161a and b, respectively (Scheme 39). The structure of 161a has been elucidated by X-ray diffraction. ${ }^{91}$

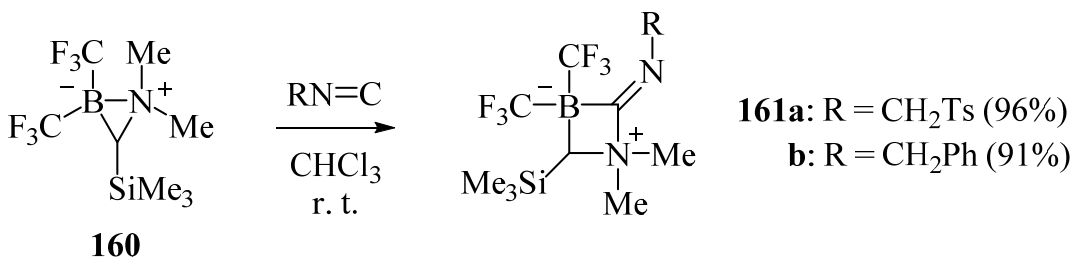

\section{Scheme 39}

Azasiliridines: For preparative reasons this class of compounds is dealt with in Section 2.2.

2H-Azaphosphirene: In the presence of a stoichiometric amount of triflic acid the azaphosphirene complex 162 underwent rapid insertion of cyclohexyl isocyanide (Scheme 40). When the reaction was quenched with triethylamine after five minutes, the dihydro-1,3-azaphosphete complex 163 was obtained in high yield. Its structural parameters have been determined by the X-ray method. Interestingly, the 3-(2-thienyl)-substituted analog of 162 did not form the corresponding product 163 (2-thienyl instead of $\mathrm{Ph}$ ), but was converted into a $2 \mathrm{H}$-azaphosphole derivative. ${ }^{92}$

Diphosphiranes, diphosphirenium: The insertion of isocyanides into the $\mathrm{P}-\mathrm{P}$ bond of diphosphiranes appears as a consequence of decomposition rather than representing a preparative concept (Scheme 40). ${ }^{93}$ Substrates like 164a-d (made from isocyanide dichlorides and alkali diphosph- 
ides) proved partially labile, depending on the Ar substituent: The derivatives a and $\mathbf{b}$ having sterically less demanding ligands released isocyanide within a few hours that reacted with residual 164a,b to give mixtures of the $E$ - and Z-configured 1,3-diphosphetane-2,4-diimines 165a,b; in the case of the derivatives $\mathbf{1 6 4 c}$,d, the bulkier substituents caused the respective conversion $\left(\rightarrow \mathbf{1 6 5}\right.$,d) to occur much more slowly. ${ }^{93}$

Another example of P-P bond breaking by an isocyanide was observed on treatment of the diphosphirenium salt 166 with tert-butyl isocyanide. As the product of insertion the 1,2-dihydro1,3-diphosphetium derivative $\mathbf{1 6 7}$ resulted, which was characterized also by X-ray diffraction. ${ }^{94}$

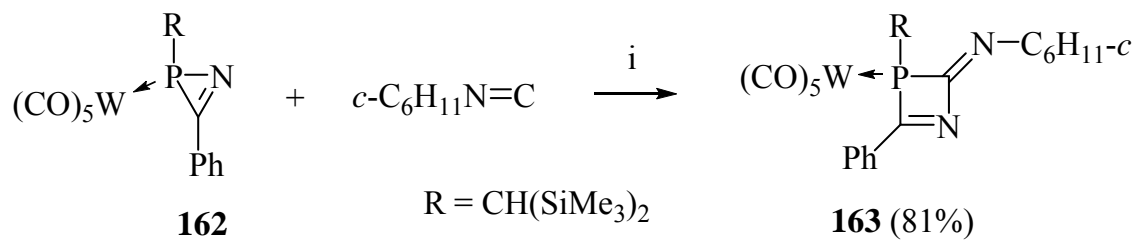

i: $\mathrm{CF}_{3} \mathrm{SO}_{3} \mathrm{H}, \mathrm{CH}_{2} \mathrm{Cl}_{2},-30{ }^{\circ} \mathrm{C}$; then $\mathrm{NEt}_{3}$

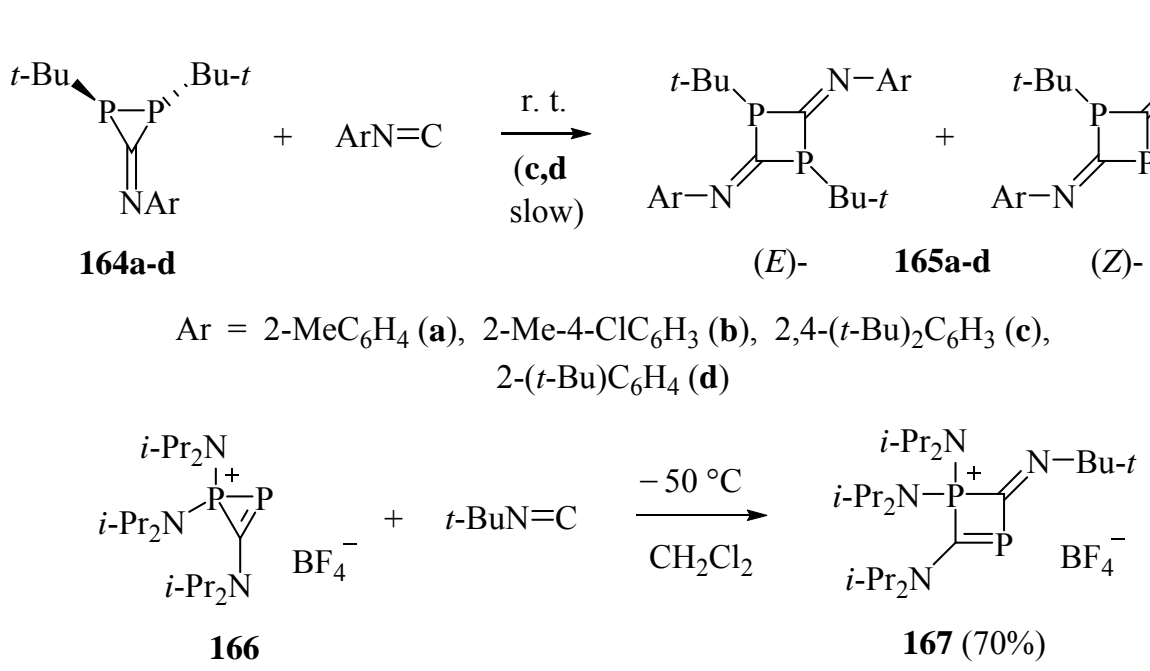

\section{Scheme 40}

Azadiboriridine: Isocyanides were found capable of breaking the $\mathrm{B}-\mathrm{B}$ bond of the azadiboridine 168 (Scheme 41). The nature of the products depends on the $\mathrm{R}$ ligand of the reagent: Usage of the sterically demanding 2,6-dimethylphenyl isocyanide (one equivalent only!) gave rise to the 1,2,4-azadiboretidin-3-imine 169a, whereas the analogous products from methyl and ethyl isocyanide, i.e. 169b,c, eluded isolation by undergoing a [3+3] cyclodimerization which led to the tricycles $\mathbf{1 7 0 b}, \mathbf{c}$. Of these derivatives, $\mathbf{1 7 0 b}$ has been submitted to an X-ray diffraction study. ${ }^{95}$

Trisilirane, trigermirane: Three-membered cycles having silicon or germanium as the sole ring atoms readily incorporate isocyanides (Scheme 42). Thus, on heating 171 with an aryl isocyanide 
the trisiletanimines 172a-d $\mathbf{d}^{96}$ and 172e-g ${ }^{97}$ were formed. Regarding 1,4-diisocyanobenzene, less than one equivalent led to the 'bis' derivative 173 which is also accessible stepwise via 172c; this product ${ }^{96}$ as well as compound $\mathbf{1 7 2 \mathbf { f } ^ { 9 7 }}$ has been studied by X-ray diffraction. The same kind of conversion occurred with the trigermirane 174 when treated with phenyl isocyanide $(\rightarrow \mathbf{1 7 5}) .{ }^{98}$

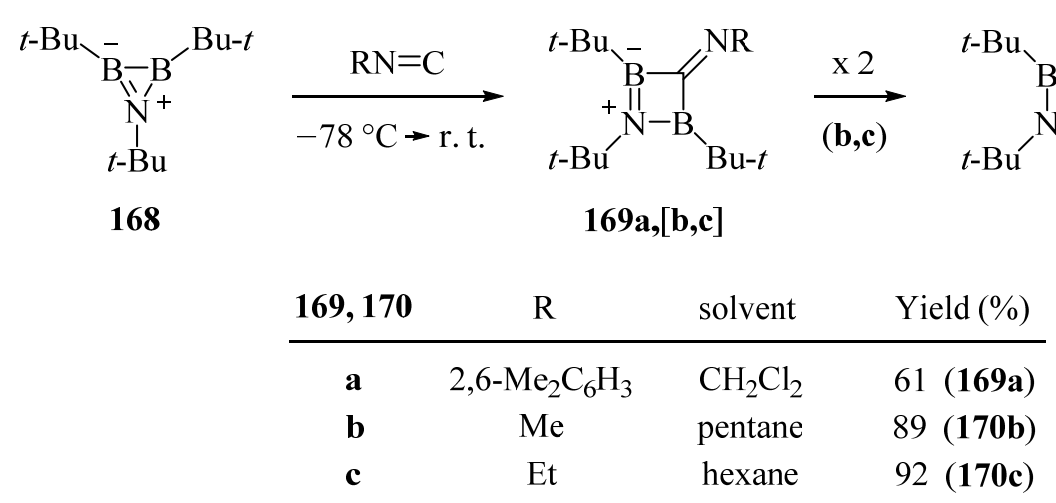

\section{Scheme 41}
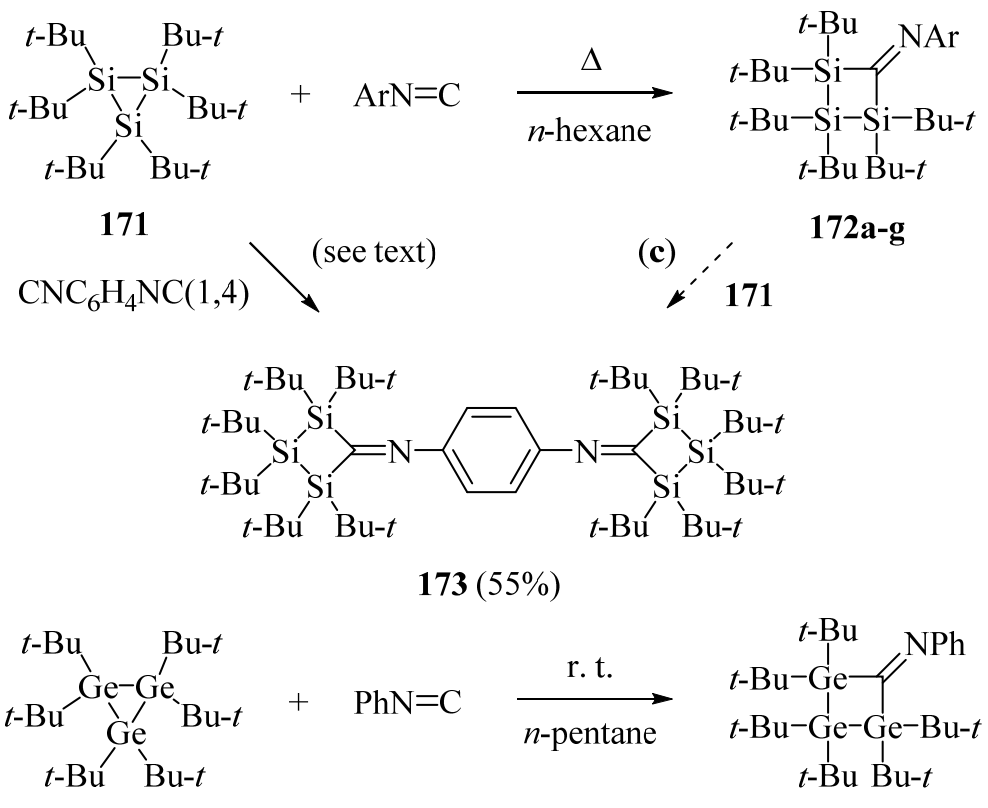

174

$175(10 \%)$

\begin{tabular}{cccccc}
$\mathbf{1 7 2}$ & $\mathrm{Ar}$ & Yield (\%) & $\mathbf{1 7 2}$ & $\mathrm{Ar}$ & Yield (\%) \\
\hline a & $\mathrm{Ph}$ & 75 & e & $2,6-\mathrm{Me}_{2} \mathrm{C}_{6} \mathrm{H}_{3}$ & 18 \\
b & $4-\mathrm{O}_{2} \mathrm{NC}_{6} \mathrm{H}_{4}$ & 68 & f & $2,6-(i-\mathrm{Pr})_{2} \mathrm{C}_{6} \mathrm{H}_{3}$ & 30 \\
c & $4-\mathrm{CNC}_{6} \mathrm{H}_{4}$ & 61 & g & 1-naphthyl & 78 \\
d & $2,4,6-\mathrm{Me}_{3} \mathrm{C}_{6} \mathrm{H}_{2}$ & 46 & & &
\end{tabular}

\section{Scheme 42}


Trisilirenes: The behavior of this class of compounds towards isocyanides is characterized by two competing reaction modes, i.e. insertion into the three-membered ring and $[1+2]$ cycloaddition across the double bond. ${ }^{99}$ Starting from the substrates 176a,b, the trisiletimines 177a,b and the trisilabicyclo[1.1.1] butanes 178a-c were prepared (Scheme 43). According to a DFT study on the models 177 and 178 having $\mathrm{R}=\mathrm{SiMe}_{3} / \mathrm{R}^{\prime}=c-\mathrm{C}_{6} \mathrm{H}_{11}$ and $2,6-\mathrm{Me}_{2} \mathrm{C}_{6} \mathrm{H}_{3}$, the derivatives 178 were found higher in energy by 2.4 and $5.1 \mathrm{kcal} / \mathrm{mol}$, showing that they arise under kinetic control. This is best demonstrated by the reaction of 176a with tert-butyl isocyanide: At room temperature a mixture of 177a and 178a was formed immediately; on standing, the latter component slowly rearranged to $177 \mathbf{a}$; yet, working at $-94{ }^{\circ} \mathrm{C}$, only compound 178a was observed. - X-ray diffraction studies have been performed with 177a,b and 178b,c (b: adduct with hexane). ${ }^{99}$

In certain cases the isocyanide opened the $\mathrm{Si}-\mathrm{Si}$ bridge in $\mathbf{1 7 8}$ to give a trisilabicyclo[1.1.1]pentane 179. This occurred on prolonged treatment of $\mathbf{1 7 6 b}$ with two equivalents of cyclohexyl isocyanide ( $\rightarrow$ 179a); using 2,6-dimethylphenyl isocyanide, the formation of $\mathbf{1 7 9 b}$ took place even in five minutes, the intermediate $\mathbf{1 7 8 d}$ being undetectable. ${ }^{99}$

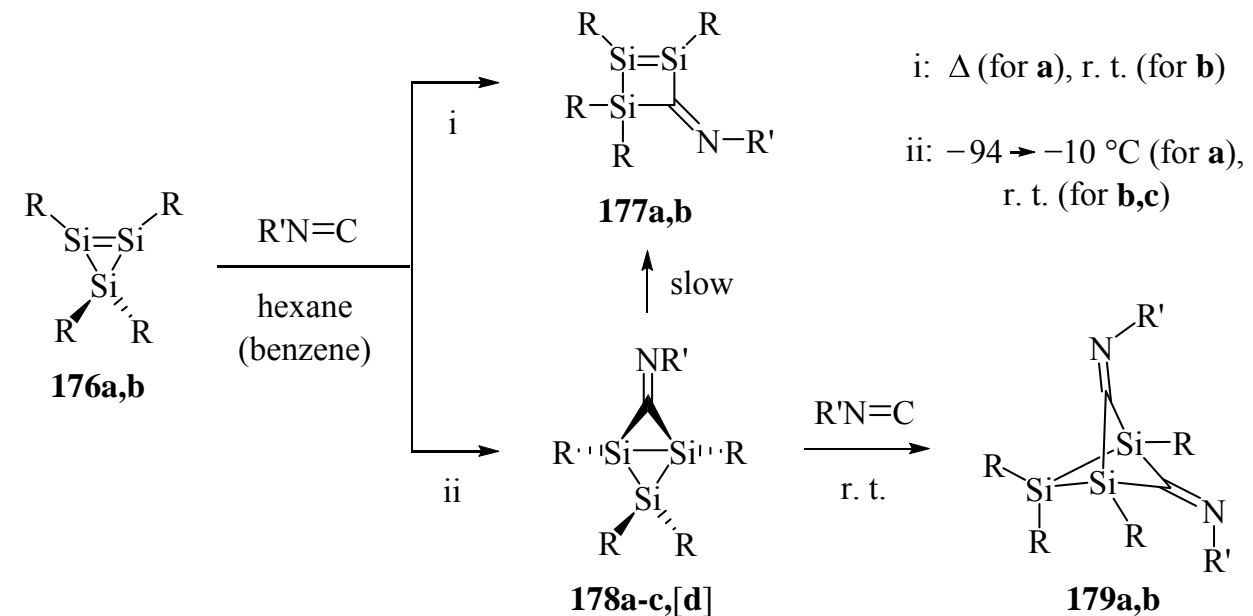

\begin{tabular}{|c|c|c|c|c|c|c|c|c|c|}
\hline 176 & 177 & 178 & 179 & $\mathrm{R}$ & $\mathrm{R}^{\prime}$ & Yield (\%) & 177 & 178 & 179 \\
\hline $\mathbf{a}$ & $\mathbf{a}$ & $\mathbf{a}$ & & $2,4,6-(i-\operatorname{Pr})_{3} \mathrm{C}_{6} \mathrm{H}_{2}$ & $t-\mathrm{Bu}$ & & 57 & 77 & \\
\hline & & b & & $2,4,6-(i-\operatorname{Pr})_{3} \mathrm{C}_{6} \mathrm{H}_{2}$ & 2,6- $-\mathrm{Me}_{2} \mathrm{C}_{6} \mathrm{H}_{3}$ & & & 85 & \\
\hline b & & c & $\mathbf{a}$ & $\operatorname{SiMe}(t-\mathrm{Bu})_{2}$ & $c-\mathrm{C}_{6} \mathrm{H}_{11}$ & & & 58 & 81 \\
\hline & b & d & b & $\operatorname{SiMe}(t-\mathrm{Bu})_{2}$ & 2,6- $-\mathrm{Me}_{2} \mathrm{C}_{6} \mathrm{H}_{3}$ & & 48 & & 39 \\
\hline
\end{tabular}

\section{Scheme 43}

\subsection{Migratory insertion of isocyanides into metallacycles}

Titanacyclobutanes: A synthetically useful synthesis of cyclobutanimines has been developed by starting from the titanacycles 180 and 183a-d (Scheme 44). ${ }^{100}$ Treatment of compound $\mathbf{1 8 0}$ with 
tert-butyl and cyclohexyl isocyanide gave, respectively, the titanacyclopentanimines 181a and $\mathbf{b}$ in $\geq 90 \%$ yield. Moderate heating of the latter induced ring contraction with demetalation to afford the cyclobutanimine $\mathbf{1 8 2}$ in $72 \%$ yield (or $94 \%$ when working in the presence of ethene).

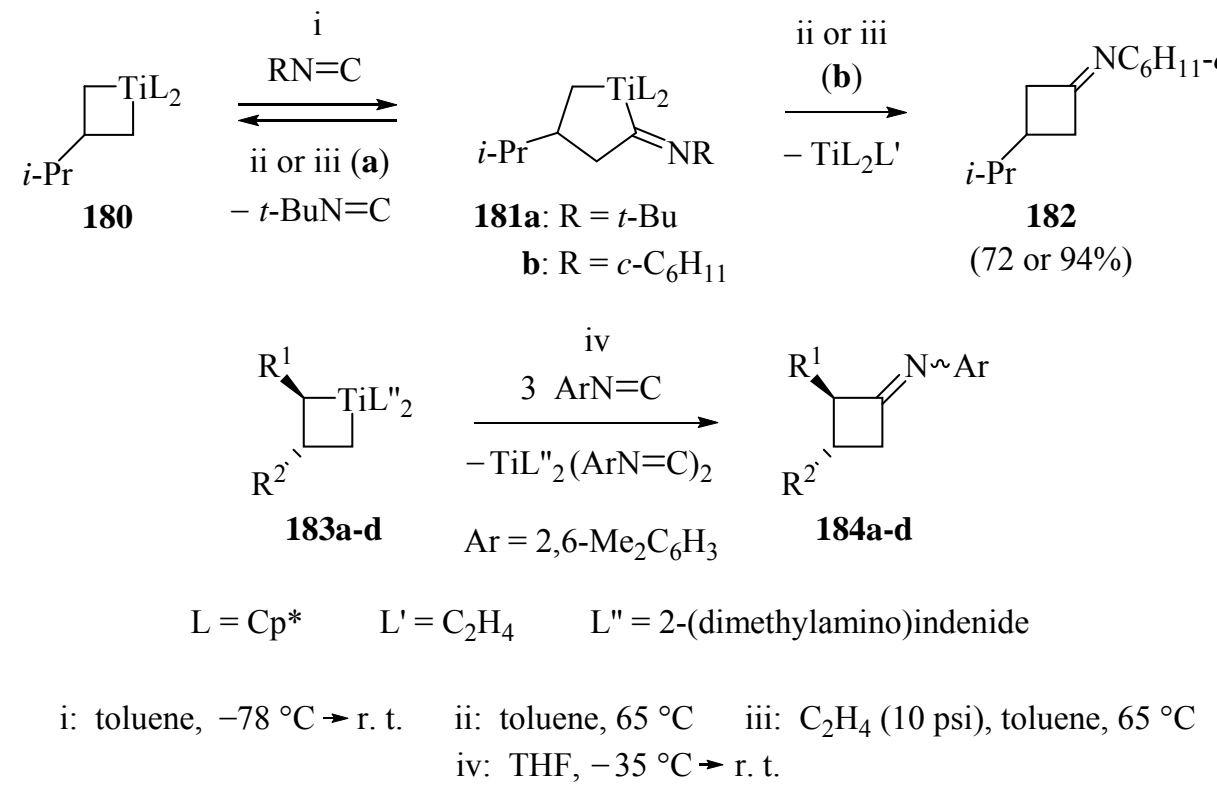

\begin{tabular}{ccccc} 
183, 184 & $\mathrm{R}^{1}$ & $\mathrm{R}^{2}$ & Yield (\%) & $E: Z$ ratio \\
\hline a & $\mathrm{Me}$ & $\mathrm{CH}_{2} \mathrm{Ph}$ & quant & $6: 1$ \\
$\mathbf{b}$ & $\mathrm{Me}$ & $i-\mathrm{Pr}$ & 90 & $>99:<1$ \\
$\mathbf{c}$ & $\mathrm{Ph}$ & $\mathrm{CH}_{2} \mathrm{Ph}$ & quant & $6: 1$ \\
d & $\mathrm{Ph}$ & $i-\mathrm{Pr}$ & 86 & $10: 1$
\end{tabular}

\section{Scheme 44}

The tert-butyl analog 181a, however, reverted to the starting ring $\mathbf{1 8 0}$ when submitted to either procedure. In a second series of experiments the authors reacted the disubstituted (transconfigured) substrates 183a-d with a threefold excess of 2,6-dimethylphenyl isocyanide. Here the intermediary five-membered rings were not isolated, but in a stereocontrolled manner directly converted into the cyclobutanimines 184a-d. ${ }^{100}$ 


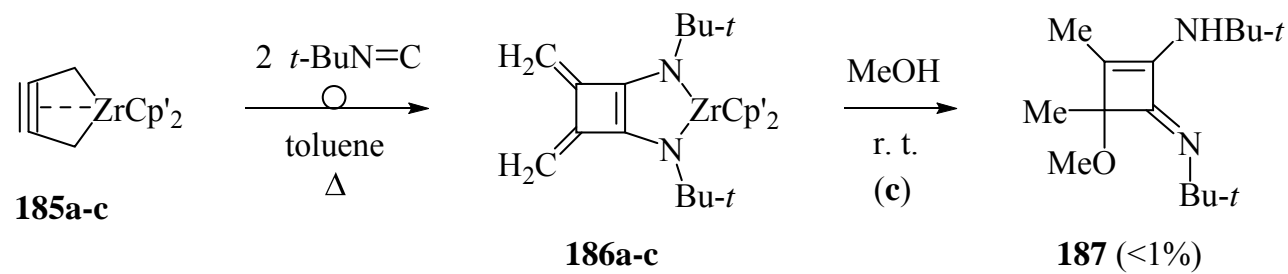

\begin{tabular}{ccc} 
185, 186 & $\mathrm{Cp}_{2}^{\prime}$ & Yield (\%) \\
\hline a & $\mathrm{Cp}_{2}$ & 85 \\
b & {$\left[\eta^{5}-(t-\mathrm{Bu}) \mathrm{C}_{5} \mathrm{H}_{4}\right]_{2}$} & 44 \\
c & $\mathrm{Me}_{2} \mathrm{Si}\left(\eta^{5}-\mathrm{C}_{5} \mathrm{H}_{4}\right)_{2}$ & 56
\end{tabular}

\section{Scheme 45}

1-Zirconacyclopent-3-ynes: Another, rather unexpected migratory insertion of an isocyanide was observed with the zirconacycles 185a-c (Scheme 45). At slightly elevated temperature two equivalents of tert-butyl isocyanide were inserted into the $\beta-\mathrm{Zr}-\mathrm{C}$ bonds, followed by a skeletal rearrangement to form the bicyclic compounds 186a-c with a four-membered half-ring. Methanolysis of the derivative 186c gave the monocycle 187 which, like the products $186 \mathrm{~b}, \mathrm{c}$, was studied by X-ray crystallography. ${ }^{101}$ - The mechanism was the subject of extensive speculations, among which the assumption of an equilibrium between structure 185 and the isomeric butatriene complex placed the reaction into the neighborhood of the process $\mathbf{4} \rightarrow \mathbf{5}$ shown in Scheme $1 .^{101}$

\subsection{Ring transformations}

3H-1,2-Dithiole-3-thiones: Under mild conditions dithiolethiones like 188a-h were transformed into the 1,3-dithietan-2-imines 189a-h on treatment with the respective isocyanides (Scheme 46). The reaction was shown to be reversible, especially at elevated temperature. Studying the scope, the authors found that substrates $\mathbf{1 8 8}$ lacking electron-withdrawing substituents were unreactive, nor did a reagent like benzyl isocyanide enter the process. ${ }^{102}$ The same kind of reaction occurred with the fused systems 190a-h to give the derivatives 191a-h. ${ }^{102,103}$ These examples demonstrate that a dithiolone moiety (as present in 190a-e) is not affected and, second, that in the case of the bis(thioxodithiolo) fused thiazines 190f-h only one of the two five-membered anellands will be involved. Moreover, replacement of the central thiazine ring in $\mathbf{1 9 0}$ with a $6 \pi$ cycle like pyrrole (which on ring transformation would lose its aromaticity) resulted in total loss of reactivity. ${ }^{102}$ 

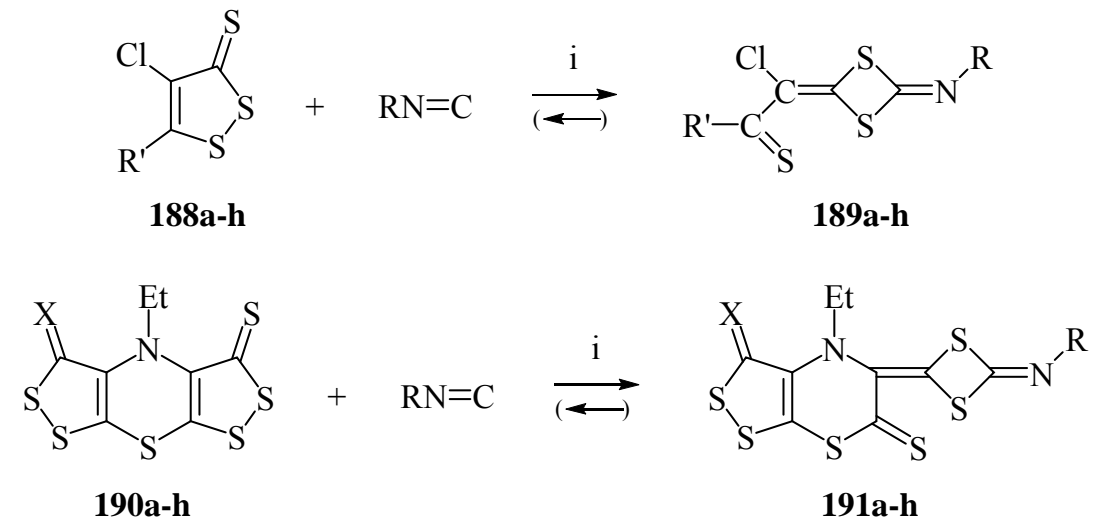

i: benzene, r. t.

\begin{tabular}{cccccccc} 
188, 189 & $\mathrm{R}^{\prime}$ & $\mathrm{R}$ & $\mathrm{Yield}(\%)$ & $\mathbf{1 9 0 , 1 9 1}$ & $\mathrm{X}$ & $\mathrm{R}$ & Yield (\%) \\
\hline $\mathbf{a} / \mathbf{e}$ & $\mathrm{Cl} / \mathrm{SPh}$ & $\mathrm{CH}_{2} \mathrm{Ts}$ & $92 / 84$ & $\mathbf{a} / \mathbf{f}$ & $\mathrm{O} / \mathrm{S}$ & $\mathrm{CH}_{2} \mathrm{Ts}$ & $64 / 61$ \\
$\mathbf{b} / \mathbf{f}$ & $\mathrm{Cl} / \mathrm{SPh}$ & $\mathrm{Ph}$ & $72 / 73$ & $\mathbf{b} / \mathbf{g}$ & $\mathrm{O} / \mathrm{S}$ & $\mathrm{Ph}$ & $38 / 42$ \\
$\mathbf{c} / \mathbf{g}$ & $\mathrm{Cl} / \mathrm{SPh}$ & $4-\mathrm{MeOC}_{6} \mathrm{H}_{4}$ & $72 / 68$ & $\mathbf{c}$ & $\mathrm{O}$ & $4-\mathrm{MeOC}_{6} \mathrm{H}_{4}$ & 74 \\
$\mathbf{d} / \mathbf{h}$ & $\mathrm{Cl} / \mathrm{SPh}$ & $4-\mathrm{NO}_{2} \mathrm{C}_{6} \mathrm{H}_{4}$ & $85 / 84$ & $\mathbf{d}$ & $\mathrm{O}$ & $4-\mathrm{NO}_{2} \mathrm{C}_{6} \mathrm{H}_{4}$ & 77 \\
& & & & $\mathbf{e} / \mathbf{h}$ & $\mathrm{O} / \mathrm{S}$ & $\mathrm{CH}_{2} \mathrm{CO}_{2} \mathrm{Et}$ & $41 / 39$
\end{tabular}

\section{Scheme 46}

3H-1,2-Dithiol-3-ones, -3-imines: Modifying the above conditions, it was found that also the hitherto unreactive 3-oxo-substituted 1,2-dithiole moiety is convertible. Experiments with both fused and monocyclic substrates revealed that a 1:2 reaction occurred to give a thiophene derivative besides an isothiocyanate, as illustrated by the process 192a,b $\rightarrow$ 193a,b (Scheme 47). ${ }^{104,105}$ To rationalize this finding, the authors invoked a transient 1,3-oxathietane (194) which via [2+2] cycloreversion generates an $\alpha$-thioxoketene that is ring-closed by the second isocyanide. ${ }^{104}$

Quite different from substrates of the type 192, imino congeners like 195a,b yielded isolable four-membered rings $(\mathbf{1 9 6 a}, \mathbf{b})$ when heated with the same isocyanide. ${ }^{106}$ 


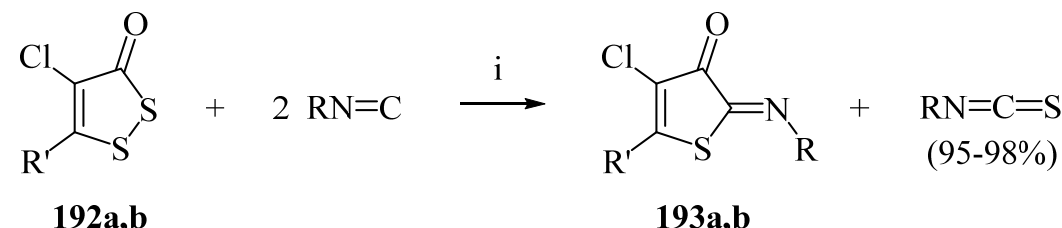

192a,b

193a,b

i $\mathrm{RN}=\mathrm{C}$

i $\mathrm{RN}=\mathrm{C}$
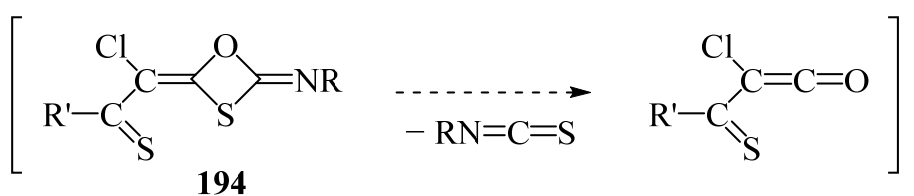

$\mathrm{R}=4-\mathrm{MeOC}_{6} \mathrm{H}_{4}$<smiles>[R]c1ssc(=[N+])c1Cl</smiles><smiles>[R]N=C1S/C(=C(/Cl)C([R])=S)N1[Al]</smiles>

$\mathrm{Ar}=4-\mathrm{NO}_{2} \mathrm{C}_{6} \mathrm{H}_{4}$

195a,b

i: $\mathrm{CCl}_{4}, \Delta$ (a) or r.t. (b)

ii: benzene, $\Delta$

196a,b

\begin{tabular}{cccccc}
$\mathbf{1 9 2 ,} \mathbf{1 9 3}$ & $\mathrm{R}^{\prime}$ & Yield (\%) & $\mathbf{1 9 5 , \mathbf { 1 9 6 }}$ & $\mathrm{R}^{\prime}$ & Yield (\%) \\
\hline $\mathbf{a}$ & $\mathrm{SPh}$ & 73 & $\mathbf{a}$ & $\mathrm{Cl}$ & 43 \\
$\mathbf{b}$ & morpholino & 54 & $\mathbf{b}$ & $\mathrm{PhO}$ & 47
\end{tabular}

\section{Scheme 47}

\section{Conclusions}

In the preceding pages we have tried to demonstrate the growing importance of isocyanides for the construction of four-membered rings. Meanwhile their diversity has gained an imposing width, as summarized below (Chart 1). Quite a number of these rings are formed with exceptional ease and are difficult to obtain by other methods. Yet, the synthetic potential of several reactions has not been fully exploited; certain transformations wait for mechanistic studies. An additional target might be the cyclic tetramerization of isocyanides to give tetraaza[4]radialenes - a pattern that is formally present in the 'four-over-one' helix $\left(4_{1}\right)$ of poly(isocyanides). ${ }^{107}$ 


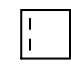

$2.1 / 2.5 / 3.1 / 3.2$<smiles>CB1CCC1</smiles>

2.1<smiles>C[Si]1(C)C=CC1</smiles>

3.1<smiles>CN1C=CC1</smiles>

$2.1 / 2.5 / 2.6 / 3.1$

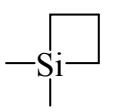

3.1

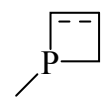

2.6<smiles>CP1(C)(C)CCC1</smiles>

2.3

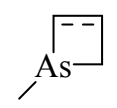

2.6

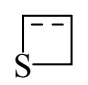

$2.5 / 3.1$

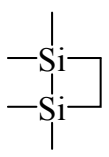<smiles>CN1CC2CC21</smiles><smiles>CB1CCN1C</smiles><smiles>CN1CC[Al]1(C)C</smiles><smiles>C[N+]1(C)CC[N+]1(C)C</smiles><smiles>CN1CC[Si]1(C)C</smiles><smiles>CN1C=C[Si]1(C)C</smiles>

2.3

$2.1 / 2.4 / 2.6$

2.6

2.6

2.4

2.6<smiles>Cn1ccp1C</smiles><smiles>CN1CCO1</smiles><smiles>C[Si]1(C)C[Si](C)(C)C1</smiles><smiles>CP1CP(C)C1</smiles>

2.2 / 3.1<smiles>CP1C[P](C)(C)C1</smiles><smiles>C[P+]1(C)C=PC1</smiles><smiles>C1SCS1</smiles>

3.1

3.3<smiles>C[B-]1(C)C[N+](C)(C)C1</smiles>

3.1<smiles>CN1C[Si](C)(C)C1</smiles>

2.2<smiles>CP1C=NC1</smiles>

3.1<smiles>C[N+]1=CP(C)C1</smiles>

2.4<smiles>CN1CSC1</smiles>

3.3<smiles>C[Si]1(C)C=[As]C1</smiles>

2.2<smiles>C1OCS1</smiles>

3.3<smiles>C[Si]1(C)C[Si](C)(C)[Si]1(C)C</smiles>

3.1<smiles>C[Si]1=[Si](C)[Si](C)(C)C1</smiles>

3.2<smiles>CC1(C)C[C@@]2(C)C[C@@]1(C)C2(C)C</smiles>

3.1

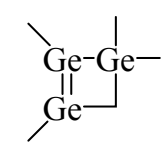

2.6<smiles>CB1CB(C)N1C</smiles>

3.1<smiles>CN1[Si](C)(C)C[Si]1(C)C</smiles>

2.6

Chart 1. Ring systems from isocyanides (numerals indicate relevant sections).

\section{References}

1. Zeeh, B. Synthesis 1969, 65. http://dx.doi.org/10.1055/s-1969-34193

2. Moderhack, D. Synthesis 1985, 1083. http://dx.doi.org/10.1055/s-1985-31437

3. A recent monograph on isocyanides contains only a limited number of examples: Nenajdenko, V. G. Ed., Isocyanide Chemistry; Wiley-VCH: Weinheim, 2012.

4. Reviewed rings of this category are limited to those having main group elements.

5. Maltsev, S. S.; Mironov, M. A.; Bakulev, V. A. Mendeleev Commun. 2006, 16, 201. http://dx.doi.org/10.1070/MC2006v016n04ABEH002354

6. Ramakrishna, T. V. V.; Lushnikova, S.; Sharp, P. R. Organometallics 2002, 21, 5685. http://dx.doi.org/10.1021/om020829h 
7. Fisher, R. A.; Buchwald, S. L. Organometallics 1990, 9, 871. http://dx.doi.org/10.1021/om00117a057

8. Lentz, D. Z. Naturforsch. 1992, 47b, 148.

9. Lentz, D. Angew. Chem. 1994, 106, 1377; Angew. Chem. Int. Ed. 1994, 33, 1315. http://dx.doi.org/10.1002/anie.199413151

10. Chatani, N.; Murai, S.; Hanafusa, T. Chem. Express 1991, 6, 339.

11. Adams, C. J.; Anderson, K. M.; Bartlett, I. M.; Connelly, N. G.; Orpen, A. G.; Paget, T. J.; Phetmung, H.; Smith, D. W. J. Chem. Soc., Dalton Trans. 2001, 1284. http://dx.doi.org/10.1039/b010018h

12. Tapper, A.; Schmitz, T.; Paetzold, P. Chem. Ber. 1989, 122, 595. http://dx.doi.org/10.1002/cber.19891220402

13. Klöfkorn, C.; Schmidt, M.; Spaniol, T.; Wagner, T.; Costisor, O.; Paetzold, P. Chem. Ber. 1995, 128, 1037. http://dx.doi.org/10.1002/cber.19951281012

14. Ansorge, A.; Brauer, D. J.; Buchheim-Spiegel, S.; Bürger, H.; Hagen, T.; Pawelke, G. J. Organomet. Chem. 1995, 501, 347. http://dx.doi.org/10.1016/0022-328X(95)05700-Y

15. Marchand, E.; Morel, G.; Sinbandhit, S. Eur. J. Org. Chem. 1999, 1729. http://dx.doi.org/10.1002/(SICI)1099-0690(199907)1999:7<1729::AIDEJOC1729>3.0.CO;2-S

16. Morel, G.; Marchand, E.; Malvaut, Y. Heteroat. Chem. 2000, 11, 370. http://dx.doi.org/10.1002/1098-1071(2000)11:5<370::AID-HC8>3.0.CO;2-J

17. Lentz, D.; Marschall, R. Z. Anorg. Allg. Chem. 1992, 617, 53. http://dx.doi.org/10.1002/zaac.19926170109

18. Weber, L.; Buchwald, S.; Lentz, D.; Stamm, O.; Preugschat, D.; Marschall, R. Organometallics 1994, 13, 4406. http://dx.doi.org/10.1021/om00023a049

19. Weber, L.; Dobbert, E.; Buchwald, S.; Stammler, H.-G.; Neumann, B. Z. Anorg. Allg. Chem. 1995, 621, 1407. http://dx.doi.org/10.1002/zaac.19956210821

20. Brook, A. G.; Kong, Y. K.; Saxena, A. K.; Sawyer, J. F. Organometallics 1988, 7, 2245. http://dx.doi.org/10.1021/om00100a033

21. Nguyen, M. T.; Vansweevelt, H.; De Neef, A.; Vanquickenborne, L. G. J. Org. Chem. 1994, 59,8015 . These authors showed in a theoretical study using $\mathrm{HN}=\mathrm{C}$ and $\mathrm{H}_{2} \mathrm{Si}=\mathrm{CH}_{2}$ as models that the respective [1+2] cycloadduct $\mathbf{2 8}$ is higher in energy than the rearranged type 29 (6.3 $\mathrm{kcal} / \mathrm{mol}$ ); a [2+2] cycloadduct (as hypothetical intermediate) was found to be even less stable $(7.6 \mathrm{kcal} / \mathrm{mol})$ : http://dx.doi.org/10.1021/jo00105a016

22. Brook, A. G.; Saxena, A. K.; Sawyer, J. F. Organometallics 1989, 8, 850. http://dx.doi.org/10.1021/om00105a049 
23. Delpon-Lacaze, G.; de Battisti, C.; Couret, C. J. Organomet. Chem. 1996, 514, 59. http://dx.doi.org/10.1016/0022-328X(95)06036-V

24. Majumdar, M.; Huch, V.; Bejan, I.; Meltzer, A.; Scheschkewitz, D. Angew. Chem. 2013, 125, 3601; Angew. Chem. Int. Ed. 2013, 52, 3516. http://dx.doi.org/10.1002/anie.201209281

25. Driess, M.; Pritzkow, H.; Rell, S.; Winkler, U. Organometallics 1996, 15, 1845. http://dx.doi.org/10.1021/om9508851

26. Driess, M.; Pritzkow, H.; Sander, M. Angew. Chem. 1993, 105, 273; Angew. Chem. Int. Ed. 1993, 32, 283. http://dx.doi.org/10.1002/anie.199302831

27. Driess, M.; Pritzkow, H. J. Chem. Soc., Chem. Commun. 1993, 1585. http://dx.doi.org/10.1039/c39930001585

28. Moderhack, D.; Lorke, M. Heterocycles 1987, 26, 1751. http://dx.doi.org/10.3987/R-1987-07-1751

29. Moderhack, D.; Lorke, M.; Ernst, L.; Schomburg, D. Chem. Ber. 1994, 127, 1633. http://dx.doi.org/10.1002/cber.19941270915

30. Moderhack, D.; Daoud, A.; Ernst, L.; Jones, P. G. J. Prakt. Chem. 2000, 342, 707. http://dx.doi.org/10.1002/1521-3897(200009)342:7<707::AID-PRAC707>3.0.CO;2-2

31. Moderhack, D.; Daoud, A.; Jones, P. G. Monatsh. Chem. 2002, 133, 1165. http://dx.doi.org/10.1007/s00706-002-0470-2

32. Moderhack, D.; Daoud, A. J. Heterocycl. Chem. 2003, 40, 625. http://dx.doi.org/10.1002/jhet.5570400411

33. Daoud, A. Ph.D. Thesis, Technical University, Braunschweig (Germany), 2003.

34. Soeta, T.; Tamura, K.; Ukaji, Y. Org. Lett. 2012, 14, 1226. http://dx.doi.org/10.1021/ol2034542

35. Grassot, J.-M.; Masson, G.; Zhu, J. Angew. Chem. 2008, 120, 961; Angew. Chem. Int. Ed. 2008, 47, 947. http://dx.doi.org/10.1002/anie.200704840

36. Moderhack, D.; Lorke, M. J. Chem. Soc., Chem. Commun. 1977, 831. http://dx.doi.org/10.1039/c39770000831

37. Ruiz, J.; Gonzalo, M. P.; Vivanco, M.; Díaz, M. R.; Garzía-Granda, S. Chem. Commun. 2011, 47, 4270 . http://dx.doi.org/10.1039/c0cc05025c

38. Lentz, D.; Anibarro, M.; Preugschat, D.; Bertrand, G. J. Fluorine Chem. 1998, 89, 73. http://dx.doi.org/10.1016/S0022-1139(98)00089-X

39. For elucidation of this mechanism, see: Amsallem, D.; Mazières, S.; Piquet-Fouré, V.; Gornitzka, H.; Baceiredo, A.; Bertrand, G. Chem. Eur. J. 2002, 8, 5306. http://dx.doi.org/10.1002/1521-3765(20021202)8:23<5305::AID-CHEM5305>3.0.CO;2-6 
40. Despagnet-Ayoub, E.; Gornitzka, H.; Bourissou, D.; Bertrand, G. Eur. J. Org. Chem. 2003, 2039. http://dx.doi.org/10.1002/ejoc.200200657

41. Weidenbruch, M.; Brand-Roth, B.; Pohl, S.; Saak, W. Angew. Chem. 1990, 102, 93; Angew. Chem. Int. Ed. 1990, 29, 90. http://dx.doi.org/10.1002/anie.199000901

42. Weidenbruch, M.; Brand-Roth, B.; Pohl, S.; Saak, W. Polyhedron 1991, 10, 1147. http://dx.doi.org/10.1016/S0277-5387(00)86090-8

43. Weidenbruch, M.; Hamann, J.; Piel, H.; Lentz, D.; Peters, K.; von Schnering, H. G. J. Organomet. Chem. 1992, 426, 35 . http://dx.doi.org/10.1016/0022-328X(92)83158-E

44. Weidenbruch, M. Coord. Chem. Rev. 1994, 130, 275. http://dx.doi.org/10.1016/0010-8545(94)80007-3

45. Xiong, Y.; Yao, S.; Driess, M. Chem. Eur. J. 2009, 15, 8542. http://dx.doi.org/10.1002/chem.200901337

46. Braunschweig, H.; Herbst, T.; Radacki, K.; Tate, C. W.; Vargas, A. Chem. Commun. 2013, 49, 1702. http://dx.doi.org/10.1039/c3ec38379b

47. Roques, C.; Mazieres, M. R.; Majoral, J.-P.; Sanchez, M. J. Org. Chem. 1989, 54, 5535. http://dx.doi.org/10.1021/jo00284a027

48. Mazieres, M. R.; Roques, C.; Khim, T.; Majoral, J.-P.; Wolf, R.; Sanchez, M. Phosphorus, Sulfur, Silicon 1990, 49/50, 309 (passim). http://dx.doi.org/10.1080/10426509008038967

49. Fernández, I.; Cossío, F. P.; Sierra, M. A. Organometallics 2007, 26, 3010. http://dx.doi.org/10.1021/om0701524

50. Aumann, R. in Organometallics in Organic Synthesis; de Meijere, A.; tom Dieck, H. Eds.; Springer: Berlin, Heidelberg et al., 1987; p 69.

51. Aumann, R. Angew. Chem. 1988, 100, 1512; Angew. Chem. Int. Ed. 1988, 27, 1456. http://dx.doi.org/10.1002/anie.198814561

52. Aumann, R.; Heinen, H.; Krüger, C. Angew. Chem. 1984, 96, 234; Angew. Chem. Int. Ed. 1984, 23, 223.

http://dx.doi.org/10.1002/anie.198402231

53. Aumann, R.; Heinen, H. Chem. Ber. 1985, 118, 952. http://dx.doi.org/10.1002/cber.19851180313

54. Aumann, R.; Kuckert, E.; Heinen, H. Angew. Chem. 1985, 97, 960; Angew. Chem. Int. Ed. 1985, 24, 978. - In this paper, an ethoxy group is erroneously taken for the methoxy substituent ( $c f$. refs. $\left.{ }^{50,51}\right)$. http://dx.doi.org/10.1002/anie.198509781

55. Aumann, R.; Krüger, C.; Goddard, R. Chem. Ber. 1992, 125, 1627. http://dx.doi.org/10.1002/cber.19921250718 
56. Aumann, R.; Heinen, H. Chem. Ber. 1987, 120, 1297.

http://dx.doi.org/10.1002/cber.19871200806

57. Aumann, R.; Heinen, H. Chem. Ber. 1988, 121, 1739. http://dx.doi.org/10.1002/cber.19881211007

58. Aumann, R.; Kuckert, E.; Krüger, C.; Angermund, K. Angew. Chem. 1987, 99, 587; Angew. Chem. Int. Ed. 1987, 26, 563. http://dx.doi.org/10.1002/anie.198705631

59. Aumann, R.; Heinen, H. Chem. Ber. 1988, 121, 1085. http://dx.doi.org/10.1002/cber.19881210611

60. Aumann, R.; Heinen, H. Chem. Ber. 1985, 118, 4186. http://dx.doi.org/10.1002/cber.19851181025

61. Aumann, R.; Heinen, H. Chem. Ber. 1986, 119, 2289. http://dx.doi.org/10.1002/cber.19861190721

62. Aumann, R.; Kuckert, E. Chem. Ber. 1987, 120, 1939. http://dx.doi.org/10.1002/cber.19871201205

63. Aumann, R.; Kuckert, E.; Krüger, C.; Goddard, R.; Angermund, K. Chem. Ber. 1988, 121, 1475 .

http://dx.doi.org/10.1002/cber.19881210822

64. Aumann, R.; Heinen, H. Chem. Ber. 1989, 122, 77. http://dx.doi.org/10.1002/cber.19891220113

65. Dyer, P.; Baceiredo, A.; Bertrand, G. Inorg. Chem. 1996, 35, 46. http://dx.doi.org/10.1021/ic9506280

66. Marrot, S.; Kato, T.; Cossío, F. P.; Gornitzka, H.; Baceiredo, A. Angew. Chem. 2006, 118, 7607; Angew. Chem. Int. Ed. 2006, 45, 7447. http://dx.doi.org/10.1002/anie.200603151

67. Junjappa, H.; Saxena, M. K.; Ramaiah, D.; Loharay, B. B.; Rath, N. P.; George, M. V. J. Org. Chem. 1998, 63, 9801. http://dx.doi.org/10.1021/jo981427f

68. The X-ray investigation announced in ref. ${ }^{67}$ could not be located.

69. Cheng, F.-Y.; Sung, K.; Lee, G.-H.; Wang, Y. J. Chin. Chem. Soc. 2000, 47, 1295.

70. Ito, Y.; Suginome, M.; Murakami, M.; Shiro, M. J. Chem. Soc., Chem. Commun. 1989, 1494. http://dx.doi.org/10.1039/c39890001494

71. Ito, Y.; Suginome, M.; Matsuura, T.; Murakami, M. J. Am. Chem. Soc. 1991, 113, 8899. http://dx.doi.org/10.1021/ja00023a043

72. Shapiro, P. J.; Vij, A.; Yap, G. P. A.; Rheingold, A. L. Polyhedron 1995, 14, 203. http://dx.doi.org/10.1016/0277-5387(94)00354-H

73. Uhl, W.; Schütz, U.; Hiller, W.; Heckel, M. Chem. Ber. 1994, 127, 1587. http://dx.doi.org/10.1002/cber.19941270906

74. Li, X.; Cheng, X.; Song, H.; Cui, C. Organometallics 2007, 26, 1039. http://dx.doi.org/10.1021/om061107j 
75. Suginome, M.; Fukuda, T.; Ito, Y. J. Organomet. Chem. 2002, 643/644, 508. http://dx.doi.org/10.1016/S0022-328X(01)01321-3

76. Hitchcock, P. B.; Lappert, M. F.; Layh, M. Angew. Chem. 1999, 111, 562; Angew. Chem. Int. Ed. 1999, 38, 501. http://dx.doi.org/10.1002/(SICI)1521-3773(19990215)38:4<501::AID-ANIE501>3.0.CO;2-Z

77. Bowen, R. J.; Fernandes, M. A.; Hitchcock, P. B.; Lappert, M. F.; Layh, M. J. Chem. Soc., Dalton Trans. 2002, 3253 (for correction, see p 3779). http://dx.doi.org/10.1039/b202629p

78. Iravani, E.; Neumüller, B. Organometallics 2005, 24, 842. http://dx.doi.org/10.1021/om0401197

79. Ramaker, G.; Saak, W.; Haase, D.; Weidenbruch, M. Organometallics 2003, 22, 5212. http://dx.doi.org/10.1021/om034123e

80. Eicher, T.; Stapperfenne, U. Synthesis 1987, 619. http://dx.doi.org/10.1055/s-1987-28024

81. Venne-Dunker, S.; Ahlers, W.; Erker, G.; Fröhlich, R. Eur. J. Inorg. Chem. 2000, 1671. http://dx.doi.org/10.1002/1099-0682(200008)2000:8<1671::AID-EJIC1671>3.0.CO;2-V

82. Temme, B.; Erker, G.; Fröhlich, R.; Grehl, M. Angew. Chem. 1994, 106, 1570; Angew. Chem. Int. Ed. 1994, 33, 1480. http://dx.doi.org/10.1002/anie.199414801

83. Ahlers, W.; Erker, G.; Fröhlich, R.; Zippel, F. Chem. Ber./Recueil 1997, 130, 1079.

84. Korotkov, V. S.; Larionov, O. V.; de Meijere, A. Synthesis 2006, 3542. https://www.thieme-connect.de/DOI/DOI?10.1055/s-2006-942514

85. Bez, G.; Zhao, C.-G. Org. Lett. 2003, 5, 4991. - Paper misquoted in ref. ${ }^{84}$ http://dx.doi.org/10.1021/o10359618

86. Li, X.; Ni, C.; Song, H.; Cui, C. Chem. Commun. 2006, 1763. http://dx.doi.org/10.1039/b601056c

87. Quast, H.; Leybach, H.; Würthwein, E.-U. Chem. Ber. 1992, 125, 1249. http://dx.doi.org/10.1002/cber.19921250535

88. Kroke, E.; Willms, S.; Weidenbruch, M.; Saak, W.; Pohl, S.; Marsmann, H. Tetrahedron. Lett. 1996, 37, 3675. http://dx.doi.org/10.1016/0040-4039(96)00650-8

89. Nguyen, P. T.; Palmer, W. S.; Woerpel, K. A. J. Org. Chem. 1999, 64, 1843. http://dx.doi.org/10.1021/jo9816257

90. Ando, W.; Hanyu, Y.; Takata, T. J. Org. Chem. 1986, 51, 2122. http://dx.doi.org/10.1021/jo00361a036

91. Brauer, D. J.; Bürger, H.; Hagen, T.; Pawelke, G. J. Organomet. Chem. 1994, 484, 107. http://dx.doi.org/10.1016/0022-328X(94)87193-0

92. Helten, H.; von Frantzius, G.; Schnakenburg, G.; Daniels, J.; Streubel, R. Eur. J. Inorg. Chem. 2009, 2062.

http://dx.doi.org/10.1002/ejic.200900190 
93. Baudler, M.; Simon, J. Chem. Ber. 1987, 120, 421.

http://dx.doi.org/10.1002/cber.19871200327

94. Soleilhavoup, M.; Baceiredo, A.; Dahan, F.; Bertrand, G. J. Chem. Soc., Chem. Commun. 1994, 337.

http://dx.doi.org/10.1039/c39940000337

95. Luckert, S.; Eversheim, E.; Müller, M.; Redenz-Stormanns, B.; Englert, U.; Paetzold, P. Chem. Ber. 1995, 128, 1029. http://dx.doi.org/10.1002/cber.19951281011

96. Weidenbruch, M.; Hamann, J.; Pohl, S.; Saak, W. J. Chem. Ber. 1992, 125, 1043. http://dx.doi.org/10.1002/cber.19921250510

97. Weidenbruch, M.; Hamann, J.; Peters, K.; von Schnering, H. G.; Marsmann, H. J. Organomet. Chem. 1992, 441, 185. http://dx.doi.org/10.1016/0022-328X(92)83378-U

98. Weidenbruch, M.; Ritschl, A.; Peters, K.; von Schnering, H. G. J. Organomet. Chem. 1992, 438, 39.

http://dx.doi.org/10.1016/0022-328X(92)88004-3

99. Ohmori, Y.; Ichinohe, M.; Sekiguchi, A.; Cowley, M. J.; Huch, V.; Scheschkewitz, D. Organometallics 2013, 32, 1591.

http://dx.doi.org/10.1021/om400054u

100. Greidanus-Strom, G.; Carter, C. A. G.; Stryker, J. M. Organometallics 2002, 21, 1011. http://dx.doi.org/10.1021/om0110080

101. Bach, M. A.; Beweries, T.; Burlakov, V. V.; Arndt, P.; Baumann, W.; Spannenberg, A.; Rosenthal, U. Organometallics 2007, 26, 4592.

http://dx.doi.org/10.1021/om700324k

102. Ogurtsov, V. A.; Karpychev, Yu. V.; Belyakov, P. A.; Nelyubina, Yu. V.; Lyssenko, K. A.; Rakitin, O. A. Izv. Akad. Nauk, Ser. Khim. 2009, 422; Russ. Chem. Bull. 2009, 58, 430. http://dx.doi.org/10.1007/s11172-010-0028-0

103. Barriga, S.; Fuertes, P.; Marcos, C. F.; Miguel, D.; Rakitin, O. A.; Rees, C. W.; Torroba, T. J. Org. Chem. 2001, 66, 5766.

http://dx.doi.org/10.1021/jo010368u

104. Ogurtsov, V. A.; Karpychev, Yu. V.; Pestravkina; D. A.; Belyakov, P. A.; Nelyubina, Yu. V.; Rakitin, O. A. Mendeleev Commun. 2010, 20, 282.

http://dx.doi.org/10.1016/j.mencom.2010.09.015

105. Ogurtsov, V. A.; Karpychev, Yu. V.; Smolentsev, A. A.; Rakitin, O. A. Phosphorus, Sulfur, Silicon 2011, 186, 1201.

http://dx.doi.org/10.1080/10426507.2010.508161

106. Ogurtsov, V. A.; Karpychev, Yu. V.; Rakitin, O. A. Izv. Akad. Nauk, Ser. Khim. 2012, 677; Russ. Chem. Bull. 2012, 61, 680. http://dx.doi.org/10.1007/s11172-012-0103-9 
107. Akeroyd, N.; Nolte, R. J. M.; Rowan, A. E. In Isocyanide Chemistry; Nenajdenko, V. G. Ed.; Wiley-VCH: Weinheim 2012; p 551.

http://dx.doi.org/10.1002/9783527652532.ch16

\section{Author's Biography}

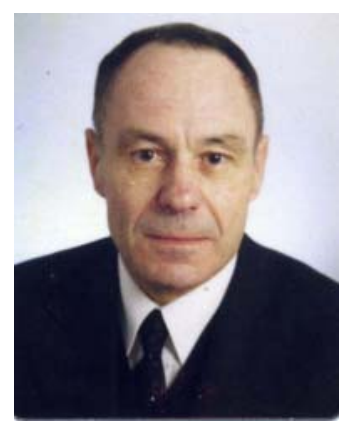

Dietrich Moderhack, born 1940 in Berlin, graduated from Technical University Braunschweig, Germany, where he took his $\mathrm{PhD}$ in 1968 (mentor: Prof. G. Zinner). From October 1974 to September 1975 he held a DFG scholarship for joining Prof. Katritzky's group at the University of East Anglia in Norwich, UK. After his Habilitation in Braunschweig (1978), he became a full Professor (1982); since October 2005, he has been retired. His major interests include triazole and tetrazole chemistry, but azapentalenes, four-membered rings with two adjacent heteroatoms and isocyanides are being looked at as well. 